\title{
The effects of fish hydrolysate (CPSP) level on Octopus maya (Voss and Solis) diet: Digestive enzyme activity, blood metabolites, and energy balance
}

\author{
Josué Aguila ${ }^{a}$, Gerard Cuzon ${ }^{b}$, Cristina Pascual ${ }^{c}$, Pedro M. Domingues ${ }^{d}$, Gabriela Gaxiola ${ }^{c}$, \\ Ariadna Sánchez ${ }^{\mathrm{c}}$, Teresita Maldonado ${ }^{\mathrm{e}}$ and Carlos Rosas ${ }^{\mathrm{c}, ~ *}$
}

\author{
${ }^{a}$ Posgrado en Ciencias del Mar, Facultad de Ciencias, UNAM. Puerto de abrigo s/n, Sisal, Yucatán, Mexico \\ IFREMER, Tahiti, French Polynesia \\ 'Universidad Nacional Autónoma de México, Facultad de Ciencias, Unidad Multidisciplinaria de Docencia e \\ Investigación, Administración de correos 1080312003, C.P.97350, Hunucmá, Yucatán, Mexico \\ "CIFAP-“Aguas del Pino" (IFAPA) Apartado 104, 21071 Huelva, Spain \\ eUniversidad Autónoma de Campeche-Facultad de Ciencias Químico Biológicas. Av. Agustín Melgar s/n C.P. \\ 24030. Campeche, Mexico \\ *: Corresponding author : Carlos Rosas, email address : crv@hp.fciencias.unam.mx
}

\begin{abstract}
:
As has been demonstrated in previous studies, Octopus maya can be fed on artificial diets. In the present study six different diets were assayed. Five diets were designed to test the effect of percentage of inclusion of fish protein concentrate (CPSP: 0, 5, 10, 15, and 20\%) and were offered to octopuses as a specifically designed artificial diet. The sixth diet consisted of frozen crab (Callinectes spp) and was used as control diet. Blood metabolites and energy budget of octopuses were evaluated to determine how CPSP levels modulate the digestive capacity and allow retaining energy for growth. Wild animals (316.4 $\pm 9.8 \mathrm{~g})$ were used in the study. Results showed that CPSP produced a positive specific growth rate (SGR, \% day- 1) with high value in octopuses fed 15\% CPSP level. A maximum growth rate of $0.86 \%$ day -1 was recorded in these animals, a value that is extremely low when compared with the SGR obtained when animals were fed fresh crab (3.7\% day- 1). In general, blood metabolites were affected by diet composition, indicating that some metabolites could reflect the nutritional and/or physiological status of octopus. Preliminary reference values for 0 . maya fed crab were found for glucose $(0.09 \pm 0.02 \mathrm{mg} / \mathrm{ml})$, lactate $(0.004 \pm 0.002 \mathrm{mg} / \mathrm{ml})$, cholesterol $(0.16 \pm 0.02$ $\mathrm{mg} / \mathrm{ml})$, acylglycerol $(0.14 \pm 0.01 \mathrm{mg} / \mathrm{ml})$, protein $(0.37 \pm 0.04 \mathrm{mg} / \mathrm{ml})$, hemocyanin $(1.85 \pm 0.04$ $\mathrm{mmol} / \mathrm{l})$, and digestive gland glycogen $(1.86 \pm 0.3 \mathrm{mg} / \mathrm{g})$. Total energy content can be used as an indicator of tissue metabolic reserves. In the present study, higher energy content in the digestive gland and muscle was observed in octopuses fed crab, followed by animals fed 15\% CPSP. Results from the digestive gland indicated that the retained energy derived from glycogen, suggesting that lipids and protein were the main sources of variation linked with energy content. In general, digestive gland proteases activity and trypsin were induced in octopuses fed 15\% CPSP. The capacity of O. maya juveniles to adjust their digestive enzymes to different types of food was evidenced. Essential amino acid content (EAA) of the diet was not a limiting factor. When dietary EAA profiles were compared with $O$. maya EAA profiles, all dietary EAA resulted in a higher concentration than whole body octopus composition. In the present study, all experimental groups ingested between 3300 and $4106 \mathrm{~kJ}$ wk- $1 \mathrm{~kg}-1$ without statistical differences among treatments, indicating that experimental diets were as attractive as crab. Differences were recorded in the proportion of absorbed energy (Ab, $\%$ ) between CPSP-based and crab meat diets, suggesting digestion limitations associated with artificial diets. The present results indicate that the 15\% CPSP diet had characteristics that stimulate digestive enzymes and reduce energetic costs associated with its digestion (HiE or SDA), channeling more biomass production than the other experimental diets.
\end{abstract}

Keywords: ctopus maya; Nutrition; Blood metabolites; Energy balance 
Fish protein soluble concentrates (also called $\mathrm{CPSP}^{80}$ ) are obtained from the liquefaction of scraps of marine animals and are characterized by a higher content of peptides and free amino acids as compared with the composition of native protein. Taking into account their composition, these products have been considered as a complement for cephalopod aquaculture diets (Le Bihan et al., 2006).

A recent study, analyzing production costs of $O$. vulgaris in Galicia, Spain (García-García et al., 2004), showed that the actual technology for rearing octopuses is a low-profit business with a high risk mainly due to food costs. Natural preys as food and acquisition of wild juveniles are expensive. For that reason, an adequate nutritional program is necessary to formulate a compounded feed for a commercially profitable production of cephalopods.

Research on artificial diets for cephalopods has been increasing in importance during the past decade. Castro (1991), using artificial diets based on shrimp paste, obtained poor survival and growth. Castro et al. (1993) used a catfish fillet-based surimi that was accepted by cuttlefish, also with poor results. A similar diet was then enriched with protein and other nutrients that promoted moderate growth (Castro \& Lee, 1994). Finally, Domingues (1999) and Domingues et al. (2005) used similar diets, supplemented with protein and amino acids for cuttlefish as well as a diet with a high protein content and adequate amino acid profile promoting moderate growth $\left(<0.5 \% \mathrm{BW} \mathrm{d}-{ }^{1}\right)$. Feeding rates obtained with any of these diets $\left(<3 \% \mathrm{BW} \mathrm{d}{ }^{-1}\right)$ were low. Although there are studies related with the effects of artificial diets on cephalopods (Castro, 1991; Castro et al., 1993; Castro and Lee, 1994; Domingues, 1999; Domingues et al., 2005), currently there is little information available to formulate adequate diets for these organisms.

Octopus maya, as other cephalopods, is a carnivorous species and protein is its main energy source (Van Heukelem, 1977; Van Heukelem, 1983; Segawa and Hanlon, 1988; Rosas et al., 2007). In a recent study using formulated diets we observed that dietary protein content modulates proteases activity. In that study, O. maya juveniles had the capacity to adjust their digestive enzymes to different types of food and protein levels. Enzymes activities appeared to be well correlated with octopus growth. General proteases and trypsin from the pancreas where well related with growth rates. A low activity was observed in octopuses fed 40\%CP diet (negative growth rate), while a high activity was present in octopuses fed 60\% CP diet and crabs. In contrast, these same enzymes were induced in the salivary glands of octopuses fed a 40\%CP diet that produced weight loss. Therefore, processes involved in digestive enzyme production in different tissues are related to the octopus capacity to recognize nutritional characteristics of the ingested food. The same trend was observed with O. vulgaris (Best and Wells, 1983; Best and Wells, 1984). An energetic evaluation was also made to determine how dietary protein level modulates energy channelled to biomass production. Finally, energy intake by octopuses fed 40 and $60 \%$ CP or crab meat was between 1000 to $1300 \mathrm{~kJ} \mathrm{~kg}^{-1}$. per week Octopuses fed artificial diets showed a very low digestible energy (DE), indicating that diets could contain a factor, such as an anti nutritional one, that would limit their digestibility.

Silages and protein concentrates have been used as a source of short peptides and amino acids for cephalopods. Le Bihan et al. (2006) found that cuttlefish fed Crangon crangon surimi soaked in silage (enriched diet) had better growth and conversion rate than cuttlefish fed a non-enriched diet. Differences between diets were the supply of low molecular weight peptides and amino acids from the ensilage that were ingested, digested, and absorbed rapidly by growing animals.

Nutritional status is considered one of the important factors that determine the ability of animals to use the ingested nutrients. In previous studies, we determined some blood metabolites and hemocyanin, together with growth and survival in the shrimp $L$. vannamei, $L$. stylirostris, and $L$. setiferus to assess the nutritional role of dietary carbohydrates and proteins (Rosas et al., 2000; 
Rosas et al., 2001a; Rosas et al., 2001b; Rosas et al., 2002). The results demonstrated that blood glucose, triacylglycerides, cholesterol, and lactate together with blood protein, hemocyanin (OxyHc), and osmotic pressure were good indicators of nutritional health. In cephalopods there is not enough information to correlate blood metabolites with growth and diet and the way in which nutrients are mobilized. At present, knowledge on blood characteristics is scarce and concentrated on few temperate species. Cephalopods have a closed circulatory system in which the blood is circulated through contractile blood vessels and capillaries by the contraction of three hearts (Wells and Smith, 1987). The blood consists of hemocyanin-rich plasma, hemolymph, and blood cells, i.e., hemocytes. The hemolymph of cephalopods, like shrimp, contains the respiratory pigment hemocyanin dissolved in the blood. Hemocyanin amounts to about $98 \%$ of the total protein present in octopus blood. The total blood volume of the Octopus dofleini was demonstrated to be $5.8 \pm 1 \%$ of the body weight (Malham et al., 1998). (Rögener et al., 1987) demonstrated that total protein and carbohydrates concentration of the hemolymph was $108 \mathrm{mg} \mathrm{ml}^{-1}$ and $0.17 \mathrm{mg} \mathrm{ml}^{-1}$, respectively, in Octopus vulgaris..

O. maya can be fed on artificial diets and our research group first used an artificial diet for O. maya based on a pellet enriched with squid paste (Domíngues et al., 2007; Rosas et al., 2007). Such a diet had $40 \%$ CP and 21\% lipids and covered maintenance energy requirements; lipids were the limiting factor for octopus growth. In a second study we tested two artificial diets with 40 and $60 \%$ $\mathrm{CP}$. Although octopuses fed $60 \% \mathrm{CP}$ showed a positive growth rate, energetic balance results showed that there was some dietary component that limited digestion. Based on those results and taking into consideration that low molecular weight of protein and amino acids could enhance digestibility of the diet, 6 different diets were assayed in the present study. Five diets were designed to test the effect of percentage of inclusion of fish protein concentrate $\left(\mathrm{CPSP}^{80}: 0,5,10\right.$, 15 and 20\%) and offered to octopuses as an artificial diet specifically designed. Frozen crab (Callinectes spp) was used as a control diet in the experiment. The way in which CPSP $^{80}$ levels modulate the digestive capacity, the accumulated energy in tissue, blood metabolites, and energetic budget of octopuses was evaluated.

\section{Material and methods}

\subsection{Animals}

Specimens of $O$. maya were caught using artisan lines, with live crabs as bait, in front of Sisal harbor (Yucatán, México). Octopuses were transported from the port to the laboratory situated 300 $\mathrm{m}$ inland, in a $120 \mathrm{~L}$ circular tank with sea water. A total of 60 octopuses were used for the experiments. In the laboratory, octopuses were placed in individual flow-through 80-L tanks with aerated sea water. A PVC tube (4" in diameter) was placed in each tank as a refuge. Octopuses were fed different CPSP levels (10 animals per diet): 0, 5, 10, 15 and 20\%. Ten other octopuses were fed frozen crabs (Callinectes spp). All the octopuses and diet combinations were randomly distributed into the 60 tanks used. All groups had similar weights $(p>0.05)$ at the start of the experiment (mean value of $316.4 \pm 9.8 \mathrm{~g}$ ). Natural filtered sea water $(5 \mu \mathrm{m})$ flowed at $120 \mathrm{~L} \mathrm{~h}^{-1}$, allowing for a complete renewal in each tank every 40 minutes. During the experiment, sea water in the tanks was maintained at $25 \pm 2^{\circ} \mathrm{C}, 36 \mathrm{psu}$, dissolved oxygen higher than $5 \mathrm{mg} / \mathrm{L}, \mathrm{pH}$ above 8 . Each tank was covered with a green solid net, sewn around the top of the tank to prevent octopuses from escaping. The octopuses were kept in the tanks during the 40 experimental days.

\subsection{Diets preparation}

Experimental diets were prepared by thoroughly mixing ingredients with oil and then adding water until a semi-humid diet resulted (Table 1). The artificial diet was prepared on a weekly basis and stored at $6^{\circ} \mathrm{C}$. Energy content was measured in a calorimetric pump (Parr ${ }^{@}$ ) calibrated with benzoic 
acid. Octopuses were fed twice a day $(0900 \mathrm{~h}$ and $1700 \mathrm{~h})$ between 7 and $10 \%$ animal $\mathrm{dw} \mathrm{d}^{-1}$ for all regimes. This ration is considered to be an adequate feeding rate for this species and cephalopods in general, at these rearing temperatures (Van Heukelem, 1983; Domingues et al., 2005).

\subsection{Amino acid profiles}

Total amino acid composition was determined with an amino acid auto analyzer, and acid hydrolysis, using method 982.30 (AOAC, 2000). Tryptophan was determined using alkaline hydrolysis following method 988.15 (AOAC, 2000).

\subsection{Blood metabolites}

Blood measurements were obtained in living fasted $(12 \mathrm{~h})$ octopuses at the end of experimentation. Animals were placed in pre-chilled $\left(15^{\circ} \mathrm{C}\right)$ and aerated seawater for $15 \mathrm{~min}$ to reduce the effect of manipulation before hemolymph extraction. Hemolymph (approximately 2-3 $\mathrm{ml}$ per animal) was individually sampled through a pre-chilled catheter inserted at the dorsal artery after the octopus had been dried with a paper towel. The individual weight $( \pm 0.05 \mathrm{~g})$ was recorded.

For oxy hemocyanin [OxyHc] measurements, $10 \mu \mathrm{l}$ hemolymph were immediately diluted with 990 $\mu \mathrm{l}$ distilled water in a 10-mm cuvette, absorbance was measured at $350 \mathrm{~nm}$. Hemocyanin concentration was calculated using an extinction coefficient of $\varepsilon=17.26$ calculated on the basis of the $74000 \mathrm{Da}$ functional subunit (Chen and Cheng, 1993). Commercial kits were used for lactate (Sigma-cat. 735), acylglycerol (TAG; GPO-PAP, Merck, cat 14354), and cholesterol (CHOD-PAP, Merck, cat. 14349). Determinations were adapted to a micro plate using $20 \mu \mathrm{l}$ of plasma obtained at $8000 \mathrm{~g}$ centrifugation and $200 \mu \mathrm{l}$ of enzyme chromogen reagent. Absorbance was recorded in a micro-plate reader (BIO-RAD model 550) and concentrations were calculated from a standard substrate solution. Plasma was further diluted 1:300 for protein (CP) determination by the (Bradford, 1976) technique adapted to a micro plate method using commercial chromogen reagent (Sigma, cat. 610) and bovine serum albumin as standard.

\subsection{Enzymatic activity}

Enzymatic activity was measured individually in octopuses fed during 40 days with each experimental diet. Salivary glands (anterior and posterior), pancreas, digestive gland, and crop were dissected and placed at $-40^{\circ} \mathrm{C}$ until analysis. All the animals were fasted $12 \mathrm{~h}$ before sampling. Frozen samples were homogenized at $4^{\circ} \mathrm{C}$ in $500 \mu \mathrm{L}$ ice-cold pyrogen-free water. Homogenates were centrifuged at $13200 \mathrm{rpm}$ for $20 \mathrm{~min}$ at $4^{\circ} \mathrm{C}$. The supernatant was diluted in 10 volumes of icecold pyrogen-free water. Homogenates were immediately used for enzyme analysis. The solubleprotein content was measured in diluted homogenates (Bradford, 1976) using the Bio-Rad protein determination kit (Biorad $\left.{ }^{@}-500-0006\right)$. Samples were read in a Biorad model 550 microplates reader at $495 \mathrm{~nm}$. Assays were made in duplicate for each sample. General proteases activity was measured in homogenates using azocoll (Sigma A-4341) as substrate in phosphate buffer, pH 7. Absorbance was read in a spectrophotometer Spectronic model 21D at $520 \mathrm{~nm}$. One unit is defined as the amount of enzyme that catalyzes the release of azo dye causing a $\Delta \mathrm{A} / \Delta \mathrm{t}=0.001 \mathrm{~min}^{-1}$. Assays were made in duplicate for each sample. Trypsin activity was measured in diluted $(1 ; 100)$ homogenates using benzoil- arginine-paranitro-anilide (BAPNAI $100 \mathrm{mM}$ ) as a substrate in a buffer (0.1M TRIS, $\mathrm{NaCl} 0.05 \mathrm{M}, \mathrm{pH} 7.5$ ), at $4^{\circ} \mathrm{C}$. Absorbance was read at $405 \mathrm{~nm}$. Leucine aminopeptidase was measured in diluted (1:10) homogenates using $100 \mathrm{mM}$ L-leucine- p-nitroanilide (LPNA) as a substrate in a bufer $\left(0.1 \mathrm{M} \mathrm{TRIS}, \mathrm{pH} 8 ; 25^{\circ} \mathrm{C}\right)$. Absorbance was read at $410 \mathrm{~nm}$. 


\subsection{Glycogen, total lipids and energy content of the digestive gland and muscle}

After measuring the total weight, the muscle and digestive gland were homogenized at $4{ }^{\circ} \mathrm{C}$ for 5 min. Glycogen from the digestive gland and muscle was extracted in the presence of sulfuric acid and phenol (Dubois et al., 1965). Tissues were first homogenized in ice-cold trichloroacetic acid $(\mathrm{TCA}, 5 \%)$ at $3,340 \mathrm{~g}$. After centrifugation $(7000 \mathrm{~g})$ the supernatant was quantified; this procedure was done twice. One milliliter of supernatant was pipetted into a tube and mixed with 5 volumes of $95 \%$ ethanol. Tubes were placed in an oven at $37-40^{\circ} \mathrm{C}$ for $3 \mathrm{~h}$. After precipitation, the tubes were centrifuged at $7000 \mathrm{~g}$ for $15 \mathrm{~min}$. The glycogen pellet was dissolved by adding $0.5 \mathrm{ml}$ of boiling water. Then, $5 \mathrm{ml}$ of concentrated sulfuric acid and phenol (5\%) were added and mixed. Tubes content was transferred to micro plates and read at $490 \mathrm{~nm}$ in a micro plate reader (Bio-Rad 550). Extraction of total lipids followed the (Bligh and Dyer, 1959) method. After phase equilibration, the lower chloroform layer (total lipids) was removed, concentrated and weighed. Total lipids were expressed as milligrams of lipids per grams of fresh tissue analyzed. Energy content of digestive gland and muscle was determined using a calorimetric pump (Parr ${ }^{@}$ ) calibrated with benzoic acid. Samples of both tissues were dried at $60^{\circ} \mathrm{C}$ until constant weight.

\subsection{Energy budget}

Food ingestion and absorption efficiency

Every day, after 4 hours in the tanks, uneaten food was removed, dried, and weighed, to determine ingestion and food conversion. The crab given to the octopuses was calculated on a dry weight basis taking into account that $100 \mathrm{~g}$ fresh crab corresponds to $18 \mathrm{~g}$ of dry biomass without shell. In this context artificial diets and fresh crab were offered to octopuses in similar rations, considering the actual dry biomass given as food in all experimental diets.

Feces were collected once a day in the tanks, except early in the morning. Feces were immediately dried in the oven to determine water content and calorimetric value. The ingestion rate (IR) was calculated as the difference between the delivered and the remnant food after $4 \mathrm{~h}$, and corrected with the percentage of leached nutrients. Remnant food was siphoned and filtered through a preweighed Wathman filter number $3(5 \mu \mathrm{m})$. The leaching percentage of the pelletized diets was measured using the shaking method (Obaldo et al., 2002). For this, $1 \mathrm{~g}$ pelleted feed was placed in $250 \mathrm{ml}$ flask placed in a horizontal shaker at $25^{\circ} \mathrm{C}$ during $2 \mathrm{~h}$. After that time, all the water was filtered through a Wathman filter number $3(5 \mu \mathrm{m})$ to separate the remaining pellet from the leached water. The leached and original feed samples were dried in a convection oven at $105^{\circ} \mathrm{C}$ for $24 \mathrm{~h}$, and then cooled in a dry environment. Dried feed samples were weighed and analyzed for dry matter retention. Pellet stability was calculated as the ratio of dry matter retention after leaching and dry matter of original samples, expressed as percentage.

The absorption efficiency of the diet (AE) was determined by using feces recovered from octopuses fed each diet. Feces were dried at $60^{\circ} \mathrm{C}$ until constant dry weight; part of the dry faeces was used to determine caloric value and part to determine ash content. The AE was determined using the equation:

$A E=[(D W A F / D W d-D W A F / D W f)) /(1-D W A F / D W f) D W A F / D W d)] \times 100$, where DWAF/DWd is the ratio between the ash-free dry weight and the dry weight of the diet, DWAF/DWf is the ratio between the ash-free dry weight and dry weight of feces. The energy absorbed ( $\mathrm{kJ}$ week ${ }^{1} \mathrm{~kg}^{-1}$ live) by octopuses was calculated as:

$\mathrm{Ab}=\mathrm{AE} * \mathrm{I}$ * $\mathrm{FE}$

where $\mathrm{I}$ is the ingestion rate ( $\mathrm{g}$ dry weight week $^{-1} \mathrm{~kg} \mathrm{live}^{-1}$ ) and FE is the food's energy content expressed as $\mathrm{kJ} / \mathrm{g}$ dry weight. Food and feces energy content were determined with a calorimetric pump (Parr ${ }^{@}$ ) calibrated with benzoic acid. All feces were pooled according to diet and dried at $60^{\circ} \mathrm{C}$ until analysis. Feces energy was obtained from 3 samples per diet burned in the calorimetric pump. Total feces energy was expressed as $\mathrm{kJ} / \mathrm{g}$ of dry weight feces. 


\subsection{Oxygen consumption and nitrogen excretion}

The effect of all diets on the physiological condition was measured in 9 animals from each diet. Octopuses were deprived of food for $12 \mathrm{~h}$ and placed individually in 80-L respirometric chambers. to measure oxygen consumption and nitrogen excretion. Tanks were sealed and connected to a flowthrough sea water recirculating system (Rosas et al., 1993). To prevent handling stress that could affect readings, octopuses were conditioned in the chambers for $12 \mathrm{~h}$ before any reading. Oxygen consumption was calculated as the difference in concentrations of the dissolved oxygen between the input and output of each chamber, timing the water flow. Dissolved oxygen was measured using the polarographic electrode of a digital oxygen meter (YSI 50B $\pm 0.01 \mathrm{mg} \mathrm{L}-1$ ). Readings were corrected with respect to the control chamber, without octopuses. Oxygen consumption was obtained every hour (between 09:30 to 18:30 h) during a 2-day period. The first day was considered as a fasting condition and on the second day animals were fed after the first (09:30 h) oxygen consumption measurement. Animals and the control chamber were fed with the frozen crab or the artificial diet, using a ration between 7 to $10 \%$ of wet weight $(w w) d^{-1}$. At the end of the second day octopuses were weighed. Routine metabolism ( $\left.R_{\text {rout }}\right)$ was estimated from the $\mathrm{VO}_{2}\left(\mathrm{mg} \mathrm{g}^{-1} \mathrm{~h}^{-1}\right)$ of unfed octopuses considering the time during the day in which octopuses do not feed. Apparent heat increase $\left(\mathrm{R}_{\mathrm{AH}} ; \mathrm{j} \mathrm{g}^{-1} \mathrm{~h}^{-1}\right)$ was estimated from the difference between $\mathrm{VO}_{2}$ of unfed octopuses and the maximum value attained after feeding and considering the time needed for peak oxygen consumption after feeding and the number of rations fed to octopuses per day $(n=2)$ during growth rate experiments. A conversion factor of oxygen consumption of $14.3 \mathrm{~J} \mathrm{mg}^{-1}$ was used to transform unfed and fed $\mathrm{VO}_{2}$ to $\mathrm{J} \mathrm{g}^{-1}$ wet weight (ww) (Lucas 1993). The AHI coefficient was calculated as $R_{A H I} / / \times 100$. Respiration $(R)$ was calculated as $R_{\text {rout }}+R_{A H I}$ and expressed as joules $d^{-1}$ $\mathrm{g}^{-1} \mathrm{ww}$ taking into consideration that octopuses were fed twice a day during growth assessments.

Nitrogen excretion was measured both before and after feeding, at the same time as oxygen consumption. Ammonia concentration was analyzed using the colorimetric indophenol method (APHA, 1995). The $U$ values were obtained transforming ammonia values, using the value of $20.5 \mathrm{~J}$ $\mathrm{mg}^{-1}$ of ammonia excretion (Lucas, 1993). The atomic ratio of O:N was estimated for both fasting and feeding animals, and recorded values of oxygen consumption and ammonia excretion were transformed to $\mu \mathrm{g}$ At $\mathrm{h}^{-1} \mathrm{~g} \mathrm{dw}^{-1}$. Feeding O:N was obtained using the maximum oxygen consumption and nitrogen excretion during the experimental period.

\subsection{Energy balance}

Energy budget was estimated using the following equations (Lucas, 1993) :

$C=A b=U+R+P$,

where $C$ is the ingested gross energy, $A b$ is the energy absorbed or digestive energy (DE), $U$ the energy lost in nitrogen products, $R$ indicates respiration $\left(R=R_{\text {rout }}+R_{A H I}\right)$, and $P$ is energy invested in biomass production. Assimilated energy (AS) was calculated as $R+P$. All values were expressed as kJ week $\mathrm{kg}^{-1}$. Energy produced $(P)$ was calculated using the actual growth rate of the octopuses obtained during the experimental time (40 days). The value of $10.09 \pm 1.3 \mathrm{~kJ} \mathrm{~g}^{-1} \mathrm{dw}$ was used to transform the growth data into production units $\left(\mathrm{P} ; \mathrm{kJ}\right.$ week $\mathrm{kg}^{-1} \mathrm{~kg}^{-1}$ live). This value was obtained from analyzing energy content applied to 25 octopuses by means of a calorimeter (Parr $\left.{ }^{\circledR}\right)$, previously calibrated with benzoic acid. Assimilated, respiratory and production gross efficiencies were calculated as

$\mathrm{As} / \mathrm{C} \times 100, \mathrm{R} / \mathrm{C} \times 100$, and P/C $\times 100$,

respectively. Respiratory $(R)$ and production net efficiencies $(P E)$ were calculated as

R/As x 100 and P/As x 100, respectively.

\subsection{Statistical analysis}

One way ANOVA was applied to results of growth rate, survival, and energetic balance. Two way ANOVA was applied to results of enzyme activity, glycogen, total lipids, and energy content, to 
determine the effects of all diets on each analyzed tissue. Arc sine transformation was used before processing percentage data (Zar, 1974).

\section{Results}

\subsection{Growth}

All the diets were well accepted by O. maya. During the experimental time a $100 \%$ of survival was observed with all treatments. Octopus fed crab showed a higher growth rate in comparison to that observed in octopuses fed artificial pastes ( $P<0.05$; Fig. 1). Negative growth rate was observed in octopuses fed the diet without CPSP ${ }^{80}$. The rest of the treatments showed a positive growth rate with maximum values in octopuses fed 15\% CPSP (Fig. 1; P < 0.05). No differences between sexes were observed among treatments. The growth rate of crab fed octopuses was (3.71\% per day), whereas the maximum growth rate of octopuses fed balanced food was ( $0.86 \%$ per day) (Fig. 1$)$.

\subsection{Blood metabolites}

Blood glucose varied between 0.06 to $0.1 \mathrm{mg} \mathrm{ml}^{-1}$ with the highest concentration in octopuses fed $10 \%$ CPSP $^{80}$ and the lowest in animals fed 20\% CPSP. Intermediate values were registered in octopuses fed $0,5,15 \% \mathrm{CPSP}^{80}$ and crab (Fig. 2a). In contrast, lactate concentration was the highest in octopuses fed 0\% CPSP $\left(0.03 \mathrm{mg} \mathrm{ml}^{-1}\right)$, intermediate in animals fed 5 to $20 \%$ CPSP $^{80}$ ( mean value of $\left.0.01 \mathrm{mg} \mathrm{ml}^{-1}\right)$ and the lowest was recorded in octopuses fed crab $\left(0.004 \mathrm{mg} \mathrm{ml}^{-1}\right.$; Fig. 2b). A similar pattern was observed for cholesterol levels with high levels in octopuses fed $0 \%$ CPSP $\left(0.37 \mathrm{mg} \mathrm{ml}^{-1}\right.$ ) and low in the rest of the diets (mean value of $0.14 \mathrm{mg} \mathrm{ml}^{-1}$ ) (Fig. 2c). Acylglycerol varied between 0.11 and $0.21 \mathrm{mg} \mathrm{m}^{-1}$ with low values in octopuses fed 0.5 and $20 \%$ CPSP and crab and high in animals 5\% CPSP. An intermediate value of $0.17 \mathrm{mg} \mathrm{ml}^{-1}$ was recorded in octopuses fed 10\% CPSP (Fig. 3d) $(P<0.05)$.

The highest value of blood protein was registered in octopuses fed $5 \%$ CPSP $\left(90.5 \mathrm{mg} \mathrm{ml}^{-1}\right.$ ) followed by animals fed 10\% CPSP $\left(63 \mathrm{mg} \mathrm{ml}^{-1}\right)$. Intermediate values were registered in octopuses fed 15, 20\% CPSP and crab $\left(44 \mathrm{mg} \mathrm{ml}^{-1}\right)$. A concentration of $21 \mathrm{mg} \mathrm{ml}^{-1}$ was observed in octopuses fed control diet. That value was lower than that registered in the rest of the octopuses (Fig. 3a; $\mathrm{P}<$ 0.05). A high value of oxy hemocyanin was obtained in octopuses fed $10 \%$ CPSP $\left(2 \mathrm{mmol}^{-1}\right)$ and $15 \%$ CPSP $\left(1.95 \mathrm{mmol}^{-1} \mathrm{I}\right)$. The rest of the octopuses showed values between 1.65 and $1.85 \mathrm{mmol}$ $\mathrm{I}^{-1}$ with a mean value of $1.78 \mathrm{mmol} \mathrm{I}^{-1}(P>0.05$; Fig. $3 \mathrm{~b})$ ).

\subsection{Glycogen, total lipids and energy content}

Octopuses fed crab showed the lowest value of digestive gland glycogen $\left(1.86 \mathrm{mg} \mathrm{g}^{-1} ; \mathrm{P}<0.05\right.$; Fig. 4). A mean value of $3.08 \mathrm{mg} \mathrm{g}^{-1}$ of glycogen was registered in octopuses fed 0 to $20 \%$ CPSP diets (Fig. 4). Digestive gland and muscle total lipids were higher in octopuses fed crab (79 and 127 $\mathrm{mg} \mathrm{g}^{-1}$ respectively) than in the rest of the treatments (Fig. 5; $\mathrm{P}<0.05$ ). Among the CPSP ${ }^{80}$ diets, the highest value of total digestive gland lipids were registered in octopuses fed the $15 \% \mathrm{CPSP}^{80}$ diet followed by octopuses fed 5,10 , and $20 \% \operatorname{CPSP}^{80}(p<0.05)$. The lowest value of total digestive gland lipids was obtained in octopuses fed the control diet (Fig. 5a). In contrast, high values of total lipids in muscle were registered in octopuses fed control, 5 and $10 \%$ CPSP $^{80}$-based diets and the lowest in animals fed 15 and 20\% CPSP diets ( $<<0.05$; Fig. 5b).

Digestive gland energy content was higher in octopuses fed $15 \%$ CPSP $^{80}$ and crab (mean value of $22 \mathrm{~kJ} \mathrm{~g}^{-1} \mathrm{dw}$ ) followed by animals fed $20 \% \operatorname{CPSP}^{80}\left(20 \mathrm{~kJ} \mathrm{~g}^{-1} \mathrm{dw}\right)$. Intermediate values were registered in octopuses fed 5 and $10 \% \mathrm{CPSP}^{80}$ diets (mean value $18.6 \mathrm{~kJ} \mathrm{~g}^{-1} \mathrm{dw}$ ) and low values were obtained in animals fed control diet $\left(14 \mathrm{~kJ} \mathrm{~g}^{-1} \mathrm{dw}\right)(P<0.05$; Fig. 6a). Muscle energy content 
followed a similar tendency as that observed in the digestive gland (Fig. 6b). However, in muscle, octopuses fed $15 \%$ CPSP $^{80}$ showed a lower energy content $\left(18.9 \mathrm{~kJ} \mathrm{~g}^{-1} \mathrm{dw}\right)$ than that observed in animals fed crab (19.7 kJ g ${ }^{-1} \mathrm{dw}$ ). In muscle, low values were observed in animals fed control and $10 \%$ CPSP diets with a mean value of $18.2 \mathrm{~kJ} \mathrm{~g}^{-1} \mathrm{dw}$.

\subsection{Digestive gland enzymes.}

Activity of general proteases followed a curve with maximum values in octopuses fed 10 and 15\% CPSP and lower values in animals fed 0, 5, 20\% CPSP and crab (Fig. 7a). Trypsin activity was high in animals fed 15\% CPSP whereas leucine amino peptidase was high in animals fed 0, 10, 15 and $20 \%$ CPSP and low in octopuses fed 5\% CPSP and crab (Figs.7b and c).

\subsection{Amino acid composition.}

In general, essential amino acids (EAA) content of experimental diets and crab was similar. Only Arg and Lys were higher in crab feed than in experimental diets (Table 2). Essential amino acids from diets, were higher concentrated than in O. maya. Only Lys content was similar in the control diet and in O. maya (Fig. 8). Non essential AA (NEAA), Cys, Trp, and Tyr, were higher in crab than in experimental diets. The rest of the NEAA were similar between diets, crab and octopus. Almost all EAA and NEAA were less concentrated in O. maya than in the experimental diets and crab. Total EAA increased according to the proportion of $\mathrm{CPSP}^{80}$ in the diet with low values with $0 \%$ CPSP (42.5 mg $100 \mathrm{~g}^{-1}$ protein) and high with $20 \% \mathrm{CPSP}^{80}$ (47 mg $100 \mathrm{~g}^{-1}$ protein) $(\mathrm{P}<0.05$; Table 2). This value was similar to those obtained in crab (48 mg $100 \mathrm{~g}-1$ protein) $(P>0.05)$. NEAA increased according to the CPSP level in the diet until 10\%, after that a reduction in NEAA was registered with 15 and $20 \%$ CPSP $^{80}$ levels (Table 2). There were no differences between NEAA in $\mathrm{CPSP}^{80}$ diets and crab $(P>0.05)$. NEAA of the diets were concentrated higher than in $O$. maya sub adults.

\subsection{Oxygen consumption and ammonia excretion}

Oxygen consumption was lower in fasting than in feeding animals, with values between 49 to $89 \mathrm{~J}$ day $^{-1} \mathrm{~g}^{-1} \mathrm{ww}, 15$ and 0 and $10 \% \mathrm{CPSP}^{80}$ (Fig. 9a). Intermediate values were registered in octopuses fed 5 and 20\% CPSP $^{80}$ and crab (mean value of $63 \mathrm{~J} \mathrm{day}^{-1} \mathrm{~g}^{-1} \mathrm{ww}$ (Fig. 9a). Feeding oxygen consumption was higher in octopuses fed 0,5 , and 10\% CPSP (mean value of $120 \mathrm{~J} \mathrm{day}^{-1} \mathrm{~g}^{-1} \mathrm{ww}$ ) than in animals fed 15, 20\% CPSP and crab (Fig. 9b).

Ammonia excretion was also lower in fasting octopuses than in feeding animals, with values that oscillated between 8.5 joules/day/g ww $\left(5 \% \mathrm{CPSP}^{80}\right)$ and $12.2 \mathrm{~J}$ day ${ }^{-1} \mathrm{~g}^{-1} \mathrm{ww}$ (crab diet) $(\mathrm{P}<0.05$; Fig. 9c). Feeding ammonia excretion was high in octopuses fed $20 \%$ CPSP and crab (24.5 J day ${ }^{-1}$ $\mathrm{g}^{-1} \mathrm{ww}$ ) and low in animals fed 0, 5, and 10\% CPSP diets (14.1 $\left.\mathrm{J}_{\text {day }}{ }^{-1} \mathrm{~g}^{-1} \mathrm{ww}\right)$.

Fasting and feeding O: $\mathrm{N}$ ratio showed that octopuses fed any of the diets had a protein metabolism (values between 6 to 14) with higher values in animals fed than in fasting animals, as well as being high in octopuses fed 0, 5 and 10\% CPSP and low in animals fed 15, 20\% CPSP ${ }^{80}$ and crab (Fig. 10a). Apparent heat increment (AHI) was higher in animals fed 5\% CPSP and lower in octopuses fed crab with intermediate values in animals fed 0,10, 15, and 20\% CPSP $^{80}$ (Fig. 10b).

\subsection{Energy balance}

Ingestion rate varied between 3368 to $4041 \mathrm{~kJ} \mathrm{week}^{-1} \mathrm{~kg}^{-1}$. There were no statistical differences among treatments, for that reason a mean value of $3620 \mathrm{~kJ}^{-1}$ week $\left.\mathrm{kg}^{-1}\right)$ was calculated $(P>0.05$; Table 3). Type of diet affected the absorption efficiency (Ab E, \%) with low values in animals fed 0 and $10 \%$ CPSP $^{80}$ (mean value of 34\%), intermediate value in octopuses fed 5, 15 and $20 \%$ CPSP $^{80}$ $(44.7 \%)$ and high values in animals fed crab (82\%) (Table 3). In consequence, the digestible 
energy (DE) was higher in animals fed crab than in the rest of treatments. A high ammonia excretion $U$ value was registered in animals fed $20 \% \mathrm{CPSP}^{80}$ and crab (mean value of $257 \mathrm{~kJ}$ week $\left.\mathrm{kg}^{-1}\right)$. The rest of the treatments showed a mean value of174.5 $\mathrm{kJ}^{-1}$ week $^{-1} \mathrm{~kg}^{-1}(P<0.05$; Table 3). An inverse relation between $\mathrm{CPSP}^{80} \%$ and $\mathrm{R}$ was observed with high values in animals fed control diet and low in octopuses fed crab (Table 3). Three groups of $R$ values could be observed. The first group was of animals fed control diet, 5 and 10\% CPSP (mean value of $850 \mathrm{~kJ}$ week $^{-1} \mathrm{~kg}^{-1}$ ). A second group was of octopuses fed 15 and 20\% CPSP (mean value of $685.4 \mathrm{~kJ}$ week $\left.\mathrm{kg}^{-1}\right)$, and data from animals fed crab $\left(605 \mathrm{~kJ}^{-1}\right.$ week $\left.^{-1} \mathrm{~kg}^{-1}\right)($ Table $3 ; \mathrm{P}<0.05)$. The highest production value $(P)$ was registered in animals fed crab $\left(1411 \mathrm{~kJ} \mathrm{week}^{-1} \mathrm{~kg}^{-1}\right)$. This value was 8times higher than the highest value registered in octopuses fed $15 \% \mathrm{CPSP}^{80}(\mathrm{P}<0.05$; Table 3$)$. Intermediate values were registered in animals fed 5 and $10 \% \mathrm{CPSP}^{80}$ with a mean value of 78.5 $\mathrm{kJ}$ week ${ }^{-1} \mathrm{~kg}^{-1}$ ). A negative $\mathrm{P}$ value of $-89.1 \mathrm{~kJ} /$ week $/ \mathrm{kg}$ was calculated for animals fed control diet. The proportion of energy assimilated that was channelled to biomass production was $70 \%$ in animals fed crab, which used the rest of the assimilated energy in metabolism (Table 3). In contrast, animals fed CPSP ${ }^{80}$ used between 80 to $93 \%$ of the assimilated energy in respiratory metabolism and the rest of the assimilated energy, between 6 to 20\%, was channelled into growth.

\section{Discussion}

In the present study we used different CPSP ${ }^{80}$ levels in an attempt to enhance the digestibility of the artificial diet and to obtain a growth rate similar to that observed when animals are fed crab. Results showed that CPSP produced a positive SGR (\% day $\left.{ }^{-1}\right)$ with high value in octopuses fed $15 \%$ CPSP level. A maximum growth rate of $0.74 \%$ day $^{-1}$ was recorded on these animals; this value was quite low compared to the SGR obtained when animals were fed fresh crab $\left(3.71 \%\right.$ day $\left.^{-1}\right)$. Rosas et al. (2007) using artificial diets enriched with squid paste obtained negative growth and only $6 \%$ of assimilation efficiency. In that study, we concluded that the lipid level in commercial pellets, nearly $20 \%$, could be the main reason limiting the digestive feed coefficient. In a more recent study, a different pellet was designed in an attempt to reduce dietary lipid concentration; an assimilation efficiency near $50 \%$ was obtained with a SGR around zero $\left(0.08 \%\right.$ day $\left.^{-1}\right)$ when octopuses were fed $60 \%$ CP (Aguila et al., 2007). In the present study a better growth rate was observed $\left(0.7 \%\right.$ day $^{-1}$ ) higher than with other artificial diets. Although the 15\% CPSP diet showed a lower SGR than that obtained in octopuses fed crab, the present results suggest that the use of fish hydrolysate could be a nutritional source to make artificial diets feasible. Differences between CPSP ${ }^{80}$ diets and crab could be related with differences in protein levels (36.8 and 58\% CP, respectively) that could limit growth rate of octopus. Diets with $15 \% \mathrm{CPSP}^{80}$ and high protein level (around $50 \% \mathrm{CP}$ ) should be made to test this hypothesis.

In the present study we are reporting for the first time some blood metabolites that could be used as nutritional condition indices. In this sense, preliminary values obtained in $O$. maya fed $\mathrm{crab}$ for glucose $\left(0.09 \pm 0.02 \mathrm{mg} \mathrm{ml}^{-1}\right)$, lactate $\left(0.004 \pm 0.002 \mathrm{mg} \mathrm{ml}^{-1}\right)$, cholesterol $\left(0.16 \pm 0.02 \mathrm{mg} \mathrm{ml}^{-1}\right)$, acylglycerol $\left(0.14 \pm 0.01 \mathrm{mg} \mathrm{ml}^{-1}\right)$, protein $\left(0.37 \pm 0.04 \mathrm{mg} \mathrm{ml}^{-1}\right)$, hemocyanin $\left(1.85 \pm 0.04 \mathrm{mmol} \mathbf{l}^{-}\right.$ $\left.{ }^{1}\right)$ and digestive gland glycogen $\left(1.86 \pm 0.3 \mathrm{mg} \mathrm{g}^{-1}\right)$ could be proposed as references taking into account that crab has been reported as the best diet for growth rate for $O$. maya and other octopus species (García-García and Aguado-Giménez, 2002; Giménez and Garcia, 2002; Aguado-Giménez and García-García, 2003; Miliou et al., 2005; Rodríguez et al., 2006; Rosas et al., 2007).

In general blood metabolites were affected by diet composition and/or presentation, indicating that some metabolites could reflect the nutritional and/or physiological status of octopus. Several authors have observed that octopuses have a limitation for carbohydrates metabolism (BoucheRodoni, 1973; Boucaud-Camou et al., 1976). Consequently, blood glucose was almost constant among treatments indicating that, independently of the CPSP ${ }^{80}$ level, carbohydrates metabolism did not change. It is interesting to note that the glucose levels observed in $O$. maya were lower than 
those of cultured shrimp Litopenaeus vannamei (0.42 $\mathrm{mg} \mathrm{m}^{-1}$; (Pascual et al., 2003) ) and wild shrimp L. setiferus $\left(0.20 \mathrm{mg} \mathrm{ml}^{-1}\right.$; (Rosas et al., 2004). Again, it is an indication of a lower carbohydrates metabolism in octopus than in shrimp.

In the present study lactate blood levels were higher in animals fed control diet than in octopuses fed CPSP $^{80}$ levels or crab, indicating that octopuses fed the control diet could be under stress conditions. In crustaceans, lactate is known as a stress indicator and has been used to evaluate the effects of air exposure in decapods (Paterson, 1993; Santos and Keller, 1993; Rivonker et al., 1997). In fact lactate can reduce $\mathrm{CO}_{2}$ transport inducing narcolepsy in crab when animals are stored out of water (Morris and Taylor, 1988). In the octopus, the metabolic pathway for lactate synthesis is related with protein metabolism. Lactate can be synthesized from threonine (thr), an essential amino acid mainly located in muscle tentacles (Akagi and Ohmori, 2004). In this sense, a high lactate level in blood could reflect a high thr metabolism in muscle, indicating that octopuses are using their essential amino acids to produce physiological fuel. Animals fed the control diet used muscle protein (presumably thr) as an energy source, produced higher levels of lactate, and lost more weight than animals on the other treatments.

In cephalopods, lipids are stored in the digestive gland and then transported to the muscle to be used as an energy source (Rosa et al., 2004). Voogt (1973) reported that cephalopods are able to synthesize sterols, although mollusks, in general, apparently can only carry out slowly this biosynthesis. For this reason the main lipids source are from food, even during reproduction (Rosa et al., 2005). Once ingested, lipids are stored in the digestive gland, used locally or transported through different tissues for energy source (Rosa et al., 2005). Fatty acids are stored as acylglycerol in the digestive gland. But, there is an inverse relation between total lipids from digestive gland (TLDG) and blood AG levels in octopuses fed CPSP ${ }^{80}$. Animals fed diets low in $\mathrm{CPSP}^{80}$ levels could mobilize more lipids from the digestive gland to compensate for low peptides and amino acid concentration. This type of response could be explained as a strategy of octopus to compensate for quality protein and quantity that were insufficient to satisfy nutritional requirements. Reduction in total muscle lipids observed in relation with increments in CPSP ${ }^{80}$ levels could prove that animals utilized energy content from lipids to compensate for an apparent low protein level in these diets. In fact, high total lipids observed in the digestive gland and muscle of octopuses fed crab evidenced that when protein quality and quantity are met, octopuses accumulate lipid as a metabolic reserve.

Total energy content can serve as an indicator of tissue metabolic reserves. In the present study, higher energy content in the digestive gland and muscle were observed in octopuses fed crab, followed by animals fed $15 \%$ CPSP $^{80}$ level. Results on digestive gland glycogen indicate that this accumulated energy was not originated by glycogen suggesting that lipids and protein were the main source of variation associated with energy content. In the digestive gland, energy content followed the same behavior as total lipids, evidencing that the energy content of the digestive gland is more related with these molecules than with protein. In contrast, in muscle there is no relation between energy content and total lipids suggesting that energy content in this tissue is mainly related with muscle protein concentration. These results reinforce the idea that CPSP ${ }^{80}$-based diets worked metabolically well, but did not provide enough protein to satisfy muscle tissue build-up.

Digestive gland total proteases and trypsin were induced in octopuses fed $15 \%$ CPSP. Thus, $O$. maya juveniles have the capacity to adjust their digestive enzymes to different types of food. The digestive adaptation could involve different reactions, whether the food meets nutritional requirements or not. Digestive enzymes can be induced as a response to growth, or in an attempt to drive more nutrients from a deficient meal (Van Wormhoudt et al., 1980). Our results showed that total proteases and trypsin from the digestive gland could be induced by CPSP ${ }^{80}$. This compound could act via a "secretagoge" role of peptides and amino acids as shown in fish (Kaiya et al., 2003). Similar results were observed in O. maya fed different protein levels (Aguila et al., 2007). Current results suggest that enzyme capacity of octopuses and, in consequence, food digestibility could be improved using nutrients that stimulate enzyme secretion. In this sense, it was found (Best and Wells, 1983; Best and Wells, 1984) that enzyme secretion can be regulated by visual, chemical 
and endocrinological stimulus. For example, 15\% $\mathrm{CPSP}^{80}$ can stimulate trypsin and total proteases activity presumably by enhancing food digestion and, consequently, improve growth rate.

Dietary essential amino acids content (EAA) was not limiting. When dietary EAA profiles were compared with $O$. maya's EAA profile, all dietary EAA had a higher concentration than whole body composition. However, in relation with crab, EAA profiles (Arg, lle and Lys) were at higher levels than in CPSP $^{80}$ diets. These EAA could make a difference between artificial diets and crab. Although the role of these EAA in $O$. maya is undefined yet, results obtained in $O$. vulgaris paralarvae suggest that by their levels, Lys, Arg, and Ile could play a protagonist role in protein metabolism of cephalopods (Villanueva et al., 2004). Arg is vigorously metabolized in cephalopods (Hochachka et al., 1983). During anaerobic work, Arg-phosphate is hydrolyzed, leading to increased availability of Arg for condensation with glucose-derived pyruvate to form octopine. Octopine is the main anaerobic end-product that accumulates in adult cephalopods during periods of exercise and stress (Hochachka et al., 1976; Storey and Storey, 1978). In adult cuttlefish S. officinalis, Argderived carbon appears in $\mathrm{CO}_{2}$, urea, ornithine, glutamate, citrulline, alanine, octopine, and proline (Hochachka et al., 1983). On the other hand, Lys has been identified as a growth promoter in S. officinalis sub-adults (Domingues, 1999) suggesting not only a high concentration but a relevant metabolic role. In consequence Lys and Arg should be tested for their nutritional requirement.

All experimental groups received between 3.3 and $4.1 \mathrm{MJ}^{\mathrm{w}} \mathrm{wk}^{-1} \mathrm{~kg}^{-1}$. Statistical differences among treatments did not exist, indicating that experimental diets where as attractive as crab. Differences where registered in the proportion of energy absorbed (Ab, \%) between CPSP ${ }^{80}$ diets and crab meat, suggesting an inferior digestion coefficient linked to artificial diets. While CPSP ${ }^{80}$-based diets revealed an Ab between 33 to 45\%, octopuses fed crab absorbed 82\%, indicating that all artificial diets were limiting in terms of digestion. Previous research on $O$. maya fed commercial diet enriched with squid (Rosas et al., in press) and high protein artificial diet (60\% CP) (Aguila et al., in press) showed that artificial diets were partially digested. Rosas et al. (2007) showed that in commercial pellets enriched with $20 \%$ squid lipid content would be a limiting factor. Thus, a low fat and high protein diet was designed and again a low digestibility was observed. For this reason, a diet with more digestible protein was designed in an attempt to improve its digestibility and enhance octopuses weight gain. In spite of the improved growth rate in comparison to other diets, Ab \% was still low. There are other dietary aspects that would limit nutrient absorption. Differences in apparent heat increment $(\mathrm{AHI})$ were observed among $\mathrm{CPSP}^{80}$ treatments with low values in animals fed $15 \%$ $\mathrm{CPSP}^{80}$ and high in octopuses fed 0 and $10 \% \mathrm{CPSP}^{80}$, suggesting that $15 \% \mathrm{CPSP}^{80}$ diet had a higher cost-benefit ratio than the other diets. AHI mirrors energy invested into mechanical and biochemical food transformation. According to the present results, the $15 \% \mathrm{CPSP}^{80}$-based diet improved mechanisms of $O$. maya to be more efficient to channel energy to biomass. Although that diet was poorly digested, O:N values recorded in octopuses fed $15,20 \% \mathrm{CPSP}^{80}$ and crab indicate that, with such diets, octopuses utilized more protein as fuel than animals fed other diets. Efficiency to derive energy from diet begins when animals ingest food and end up when that energy is deposited as biomass or used as metabolic energy. In cephalopods, this process is mainly driven by protein metabolism.

A $15 \%$ CPSP $^{80}$-based diet has characteristics that stimulate digestive enzymes and reduce energetic costs linked with digestion. It helped biomass production more than the other experimental diets. An amino acids requirement definition is needed. The use of other protein sources will be tested further in an attempt to obtain a balanced compound feed able to sustain octopus biomass production. Animals fed crab will still serve as a reference.

\section{Acknowledgments}

The present study was partially financed by DGAPA-UNAM project No: IN216006-3, and SAGARPA-CONACYT 2005-11720. Thanks are given to CONACYT for the fellowship to JA and we appreciate the technical assistance of Darwin Chay and Julia Tut during the course of the experiments. 


\section{Reference List}

Aguado-Giménez,F., García-García,B., 2003. Growth and food intake models in Octopus vulgaris Cuvier (1797): influence of body weight, temperature, sex and diet. Aquaculture International 10, 361-377.

Akagi,S., Ohmori,S., 2004. Threonine is the best substrate for D-lactate formation in octopus tentacle. Amino Acids 26, 169-174.

APHA, 1995. Standard methods for the examination of water and wastewater., 19 ed. American Public Health Association.

Best,E.M.H., Wells,M.J., 1983. The control of digestion in Octopus. I. The anticipatory response and the effects of severing the nerves to the gut. Vie et Millieu 33, 135-142.

Best,E.M.H., Wells,M.J., 1984. The contrl of digestion in Octopus. II. The role of internal stimulus. Vie et Millieu 34, 1-7.

Bligh,E.G., Dyer,W.J., 1959. A rapid method of total lipid extraction and purification. Can. J. Biochem. Physiol. 37, 911-931.

Boucaud-Camou,E., Boucher-Rodoni,R., Mangold,K., 1976. Digestive absorption in Octopus vulgaris (Cephalopoda: Octopoda). J. Zool. 179, 261-271.

Bouche-Rodoni,R., 1973. Vitesse de digestion d'Octopus cyanea (Cephalopoda: Octopoda). Mar. Biol. 18, 237-242.

Bradford,M.M., 1976. A refined and sensitive method for the quantitation of microgram quantities of protein utilizing the principle of protein-dye binding. Anal. Biochem. 72, 248.

Castro,B., 1991. Can Sepia officinalis L. Be reared on artificial food? Mar. Behav. Physiol. 19, 3538.

Castro,B., DiMarco,F.P., DeRusha,R., Lee,P.G., 1993. The effects of surimi and pelleted diets on the laboratory survival, growth and feeding rate of the cuttlefish Sepia officinalis. J. J. Exp. Mar. Biol. Ecol. 170, 241-252.

Castro,B., Lee,P.G., 1994. The effects of semi-purified diets on growth and condition of Sepia officinalis L. (Mollusca: Cephalopoda). Comp. Biochem. Physiol. 109A , 1007-1016.

Chen,J.C., Cheng,S.-Y., 1993. Hemolymph $\mathrm{PCO}_{2}$, hemocyanin, protein level and urea excretions of Penaeus monodon exposed to ambient ammonia. Aquatic Toxicology 27, 281-292.

Domingues,P., 1999. Development of alternative diets for the mass culture of the European cuttlefish Sepia officinalis. University of the Algarve, Portugal, pp. 1-95.

Domingues,P., DiMarco,F.P., Andrade,J.P., Lee,P.G., 2005. Effect of artificial diets on growth, survival and condition of adult cuttlefish, Sepia officinalis Linnaeus, 1758. Aquaculture International 13, 423-440.

Dubois,M.K., Lilles,L.A., Hamilton,J.C., Rebers,P.A., Smith,F., 1965. Cholorimetric method for determination of sugars and related substances. Analyt. Chem. 28, 350-356. 
García-García,B., Aguado-Giménez,F., 2002. Influence of diet on growing and nutrient utilization in the common octopus (Octopus vulgaris). Aquaculture 211, 173-184.

García-García,J., Rodríguez-González,L.M., García-García,B., 2004. Estudio económico de una explotación tipo de engorde de Pulpo ( Octopus vulgaris) en Galicia, mediante la analítica de costes. Aquatic 21, 24-33.

Giménez,F.A., Garcia,E., 2002. Growth and food intake models in Octopus vulgaris Couvier (1797): Influence of body weight, temperature, sex and diet. Aquaculture International 10, 361-367.

Hochachka,P.W., Hartline,P.H., Fields,J.H.A., 1976. Octapine as an end product of anaerobyc glycolisis in the chambered nautilus. Science 195, 72-74.

Hochachka,P.W., Mommsen,T.P., Storey,K.B., Johansen,K., French,C.J., 1983. The relationship between arginine and proline metabolism in cephalopods. Mar. Biol. Lett. 4, 1-21.

Kaiya,H., Kojima,M., Hosoda,H., Moriyama,S., Takahashi,T., Kawauchi,K., Kangawa,K., 2003. Peptide purification, cDNA and genomic DNA cloning, and functional characterization of ghrelin in rainbow trout. Endocrinology 144, 5215-5226.

Le Bihan,E., Perrin,A., Koueta,N., 2006. Influence of diet peptide content on survival, growth and digestive enzymes activities of juvenile cuttlefish Sepia officinalis. Vie et Millieu 56, 139145.

Lucas,A., 1993. Bioénergétique Des Animaux Aquatiques. Masson, Paris.

Malham,S.K., Coulson,C.L., Runham,N.W., 1998. Effects of repeated sampling on the haemocytes and haemolymph of Eledone cirrohosa (Lam.). Com. Biochem. Physiol. 121A, 431-440.

Miliou,H., Fintikaki,M., Kountouris,T., Verriopoulos,G., 2005. Combined effects of temperature and body weight on growth and protein utilization of the common octopus Octopus vulgaris. Aquaculture 249, 245-256.

Morris,S., Taylor,C., 1988. L-Lactate affects CO2 transport in crustacean hemolymph. Comp. Biochem. Physiol. 91A, 523-527.

Obaldo,L.G., Divakaran,S., Tacon,A.G., 2002. Method for determining the physical stability of shrimp feeds in water. Aquac Research 33(5), 369-377.

Pascual,C., Gaxiola,G., Rosas,C., 2003. Blood metabolites and hemocyanin of the white shrimp Litopenaeus vannamei: the effect of culture conditions and a comparison with other crustacean species. Marine Biology 142, 735-745.

Paterson,B.D., 1993. The rise in inosine monophosphate and L-lactate concentrations in muscle of live penaeids prawns (Penaeus japonicus, Penaeus monodon) stressed by storage out of water. Comp. Biochem. Physiol. 106B(2), 395-400.

Rivonker,C.U., Thakur,J.K., Sangodkar,U.M.X., 1997. Food utilization, growth and lactate dehydrogenase activity of the prawn, Metapenaeus dobsoni (Miers) fed with commercial diet. Indian journal of marine sciences. New Delhi [Indian J. Mar. Sci. ] 26(4), 356-360.

Rodríguez,C., Carrasco,J.F., Arronte,J.C., Rodríguez,M., 2006. Common octopus (Octopus vulgaris Cuvier, 1797) juvenile ongrowing in floating cages. Aquaculture 254, 293-300. 
Rögener,W., Renwrantz,L., Uhlenbruck,G., 1987. Analysis of Octopus vulgaris hemolymph containing a glycoprotein with blood group A-like properties. Comp. Biochem. Physiol. 86, 347-351.

Rosa,R., Costa,P.R., Bandarra,N., Nunes,A.J.P., 2005. Changes in Tissue Biochemical Composition and Energy Reserves Associated With Sexual Maturation in the Ommastrephid Squids Illex coindetii and Todaropsis eblanae . Biol. Bull. 208, 100-113.

Rosa,R., Costa,P.R., Nunes,L., 2004. Effect of sexual maturation on the tissue biochemical composition of Octopus vulgaris and O. defilippi(Mollusca: Cephalopoda). Mar. Biol. 145, 563-574.

Rosas,C., Cooper,E.L., Pascual,C., Brito,R., Gelabert,R., Moreno,T., Miranda,G., Sánchez,A., 2004. Indicators of physiological and immunological status of Litopenaeus setiferus wild populations (Crustacea, Penaeidae). Marine Biology 145, 401-413.

Rosas,C., Cuzon,G., Gaxiola,G., LePriol,Y., Pascual,C., Rossignyol,J., Contreras,F., Sánchez,A., Van Wormhoudt,A., 2001a. Metabolism and growth of juveniles of Litopenaeus vannamei: effect of salinity and dietary carbohydrate levels. Journal Experimental Marine Biology and Ecology 259, 1-22.

Rosas,C., Cuzon,G., Gaxiola,G., Arena,L., Lemaire,P., Soyez,C., Van Wormhoudt,A., 2000. Influence of dietary carbohydrate on the metabolism of juvenile Litopenaeus stylirostris. Journal Experimental Marine Biology and Ecology 249, 181-198.

Rosas,C., Cuzon,G., Gaxiola,G., Pascual,C., Taboada,G., Arena,L., VanWormhoudt,A., 2002. An energetic and conceptual model of the physiological role of dietary carbohydrates and salinity on Litopenaeus vannamei juveniles. Journal of Experimental Marine Biology and Ecology 268, 47-67.

Rosas,C., Cuzon,G., Pascual,C., Gaxiola,G., Chay,D., López,N., Maldonado,T., Domingues,P.M., 2007. Energy balance of Octopus maya fed crab and artificial diet. Marine Biology In press.

Rosas,C., Cuzon,G., Taboada,G., Pascual,C., Gaxiola G., Van Wormhoudt,A., 2001b. Effect of dietary protein and energy levels (P/E) on growth, oxygen consumption, hemolymph and digestive gland carbohydrates, nitrogen excretion and osmotic pressure of Litopenaeus vannamei and L. setiferus juveniles (Crustacea, Decapoda ; Penaeidae). Aquac Research 32, 1-20.

Rosas,C., Vanegas,C., Tabares,I., Ramirez J., 1993. Energy balance of Callinectes rathbunae Contreras 1930 in floating cages in a tropical coastal lagoon. Journal of the World Aquaculture Society 24, 71-79.

Santos,E., Keller,R., 1993. Effect of exposure to atmospheric air on blood glucose and lactate concentrations in two crustacean species: a role of the crustacean hyperglycemic hormone (CHH). Comp. Biochem. Physiol. 106A(2), 343-347.

Segawa,S., Hanlon,R.T., 1988. Oxygen Consumption and Ammonia Excretion Rates in Octopus maya, Loligo forbesi and Lolliguncula brevis (Molluscs : Cephalopoda). Mar. Behav. Physiol. 13, 389-400.

Storey,K.B., Storey,J.M., 1978. Energy metabolism in the mantle muscle of the squid Loligo pealeii. J. Comp. Physiol. 123, 169-175.

Van Heukelem,W.F., 1983. Octopus maya. Cephalopod Life Cycles. Academic Press, London., pp. 311-323. 
Van Heukelem,W.F., 1977. Laboratory maintenance, breeding, rearing and biomedical research potential of the Yucatan octopus (Octopus maya). Lab. Anim. Sci. 27, 852-859.

Van Wormhoudt,A., Ceccaldi,J.H., Martin,B.J., 1980. Adaptation de la teneur en enzymes digestives de l'hepatopancreas de Palaemon serratus (Crustacea Decapoda) a la composition dáliments experimentaux. Aquaculture 21, 63-78.

Villanueva,R., Riba,J., Ruíz-Capillas,C., González,A.V., Baeta,M., 2004. Amino acid composition of early stages of cephalopods and effects of amo acid dietary treatmets on Octopus vulgaris paralarvae. Aquaculture 242, 455-478.

Wells,J., Smith,P.J.S., 1987. The performance of the octopus circulatory system: a triumph of engineering over design. Experientia 43, 487-499.

Zar,J.H., 1974. Bioestatistical Analysis. Prentice Hall, Englewood Cliff. 
Figures

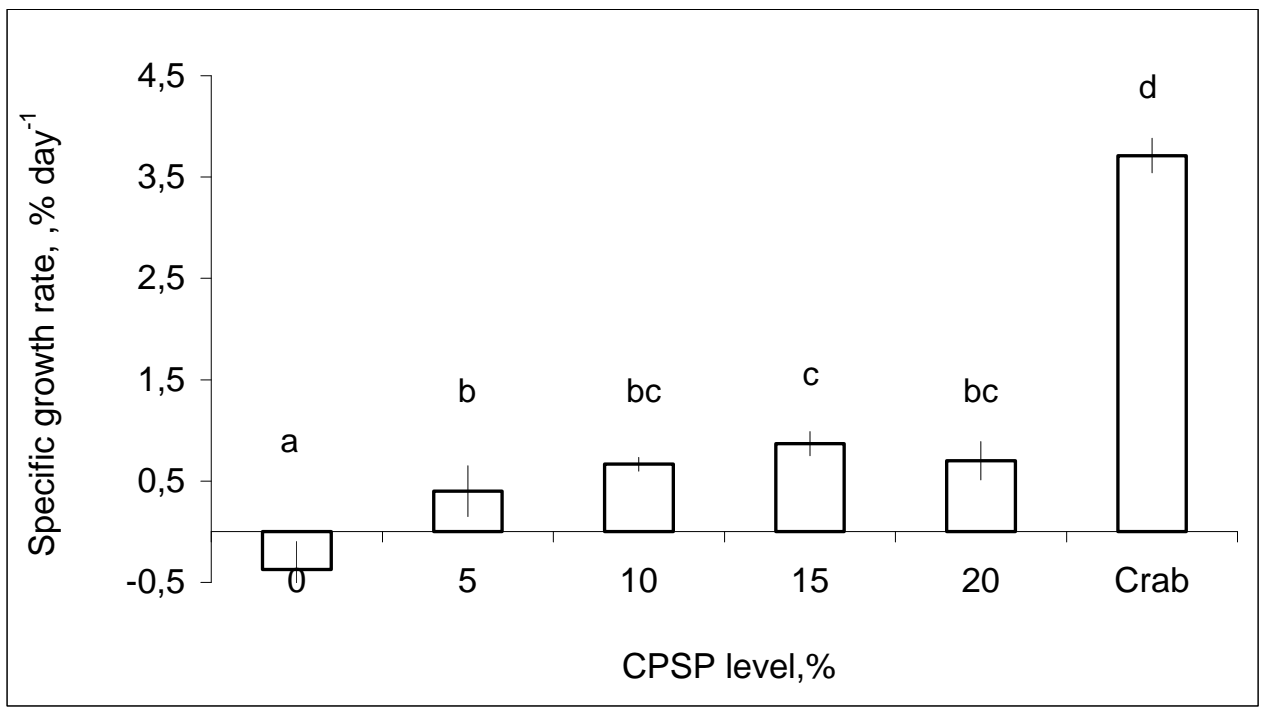

Fig.1. Specific growth rate $\left(\%\right.$ day $\left.^{-1}\right)$ of $O$. maya fed different CPSP $^{80}$ levels or fresh crab. Mean \pm S.E. Different letters mean differences $(p<0.05)$ among treatments. 

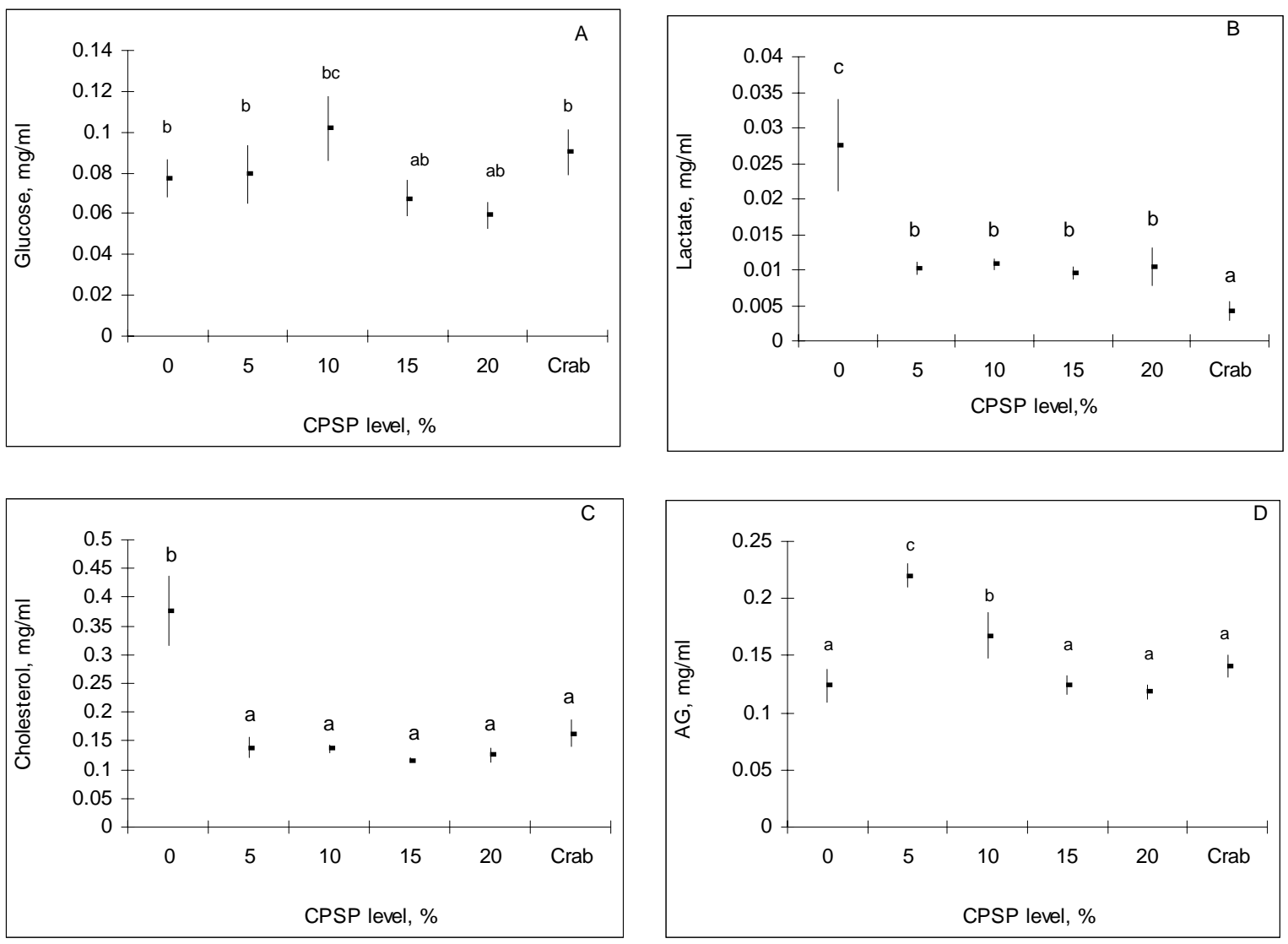

Fig. 2. Blood glucose, lactate, cholesterol and acylglycerol (AG) of O. maya fed different CPSP levels or fresh crab. Mean + S.E. Different letters mean differences among treatments at a $p<0.05$ level. 

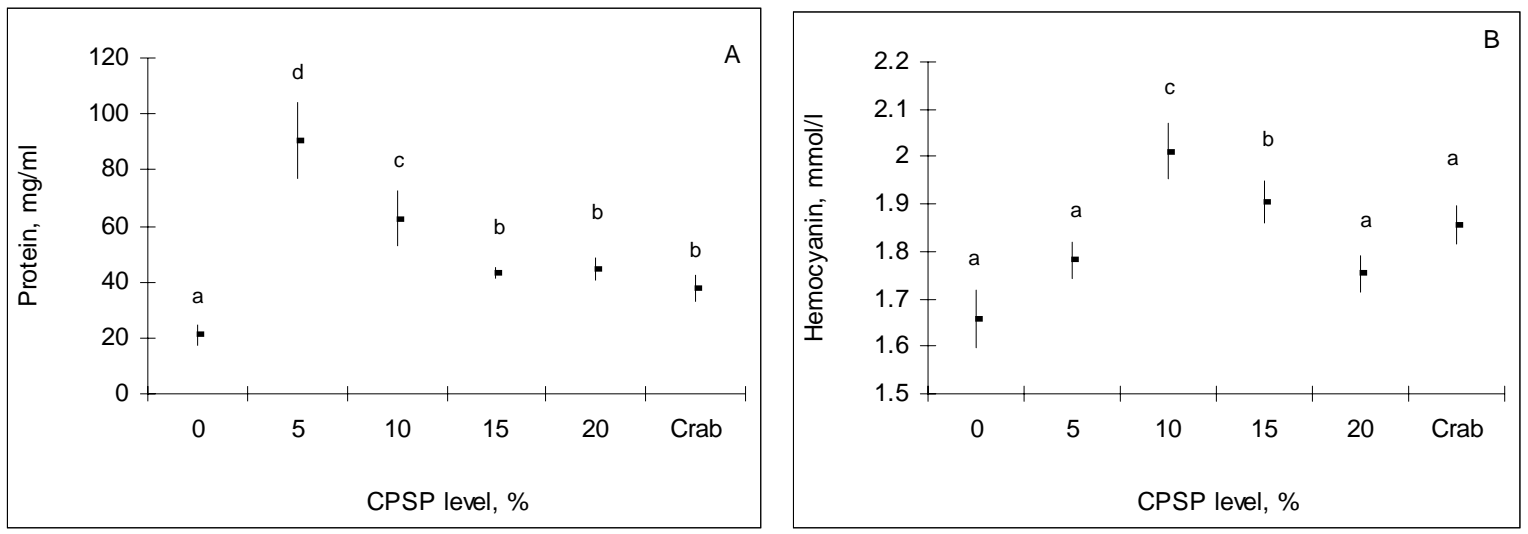

Fig. 3. Blood protein (A) and hemocyanin (B) of O. maya fed different CPSP levels or fresh crab. Mean \pm S.E. Different letters mean differences between treatments at a $p<0.05$ level.

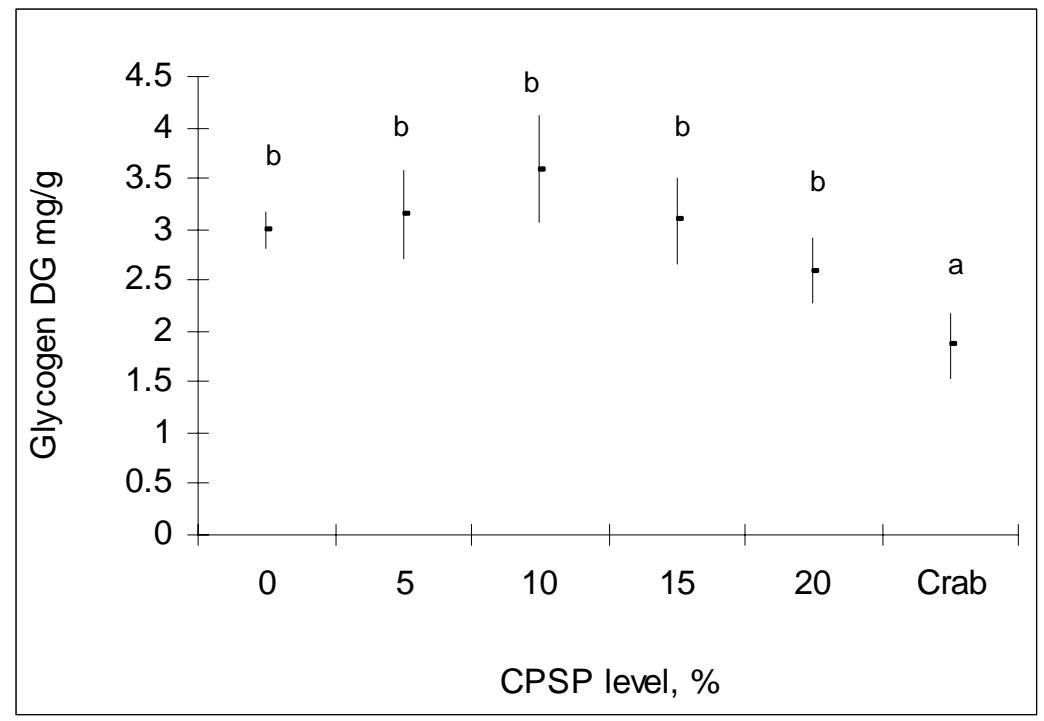

Fig. 4. Digestive gland glycogen of $O$. maya fed different CPSP levels or fresh crab. Mean \pm S.E. Different letters mean differences between treatments at a $p<0.05$ level. 

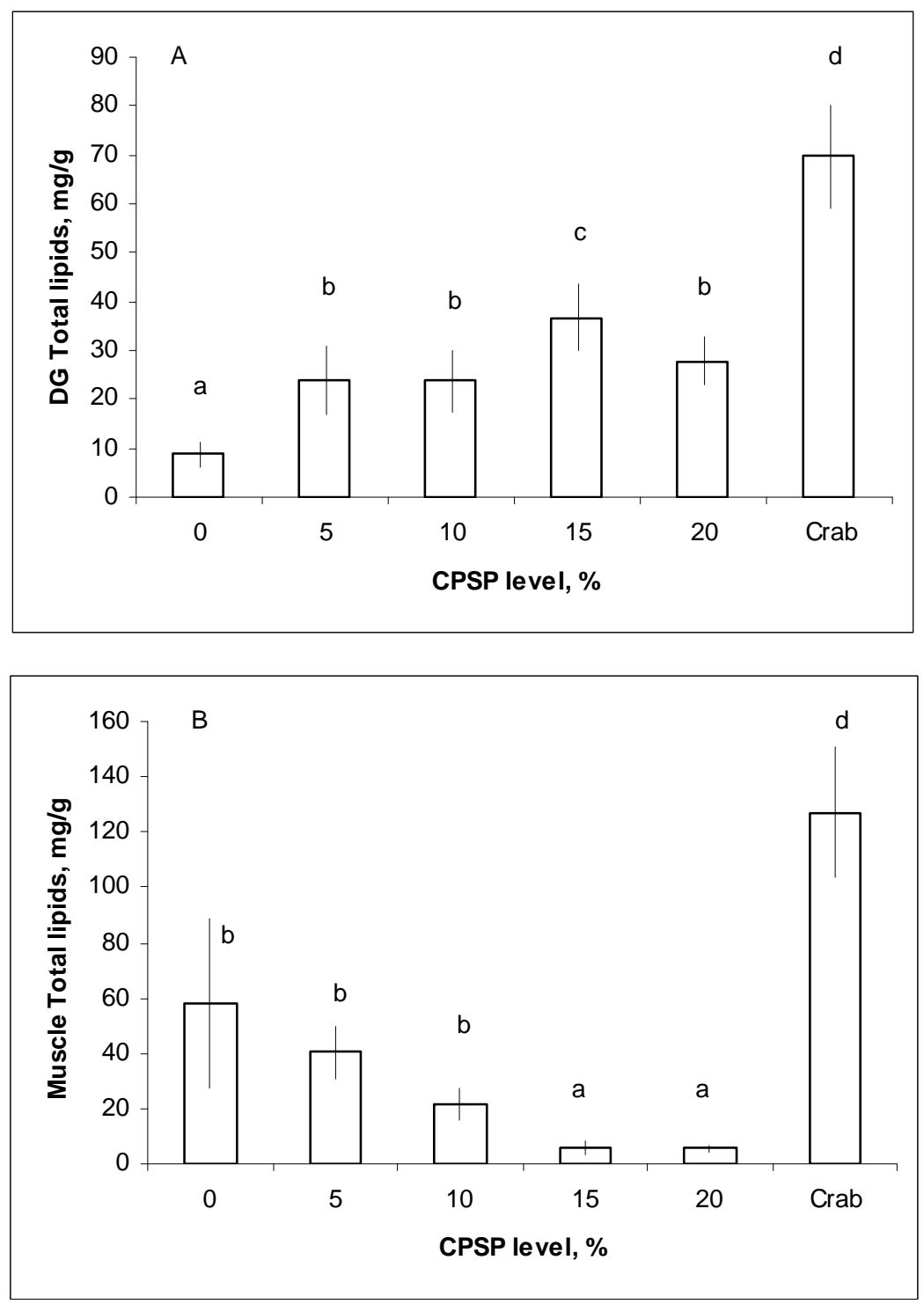

Fig. 5. Total lipids of digestive gland $(A)$ and muscle $(B)$ of $O$. maya fed different CPSP levels or fresh crab. Mean \pm S.E. Different letters mean differences among treatments at a $p<0.05$ level. 

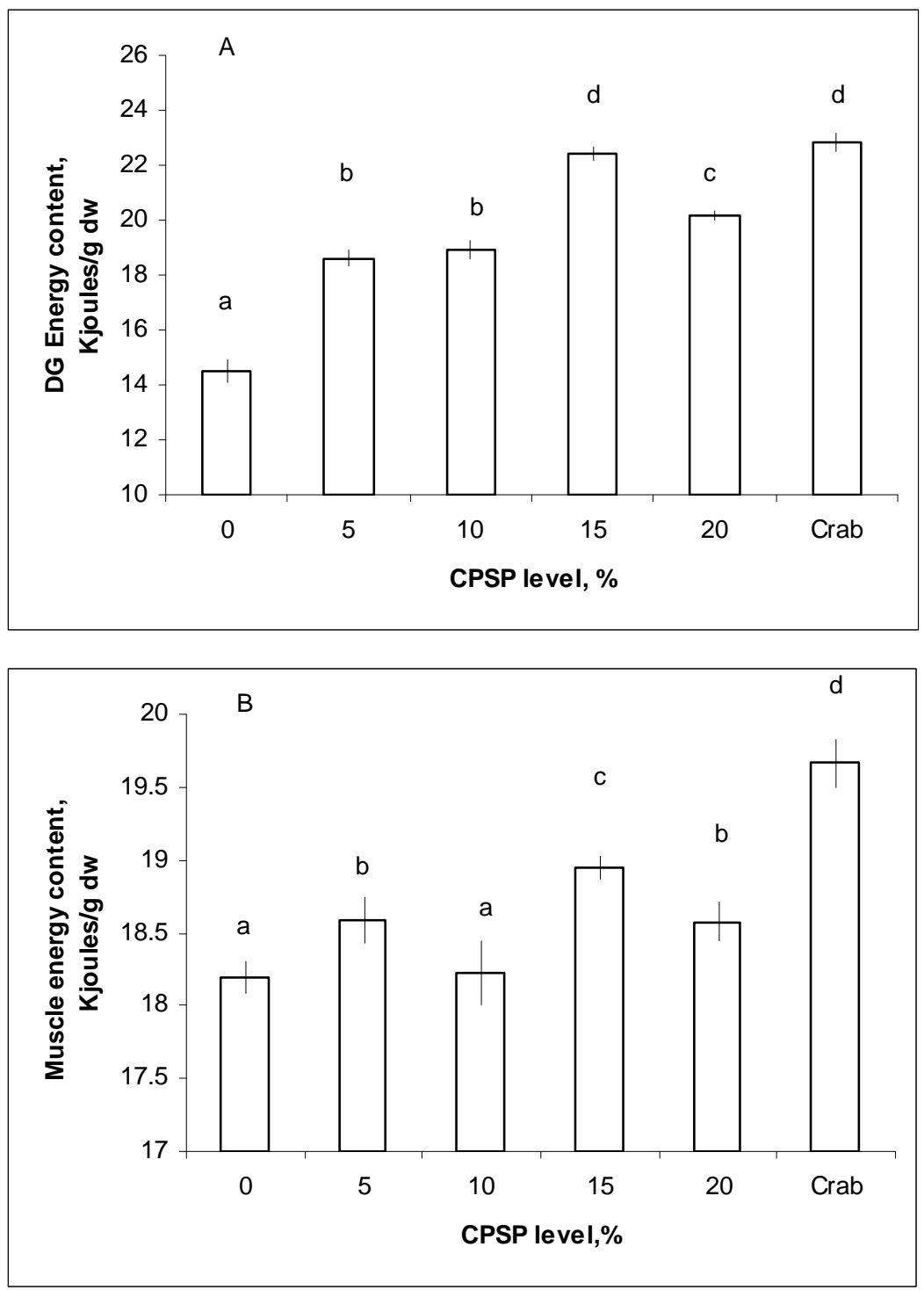

Fig. 6. Energy content of digestive gland $(A)$ and muscle $(B)$ of $O$. maya fed different CPSP levels or fresh crab. Mean \pm S.E. Different letters mean differences among treatments at a $p<0.05$ level. 

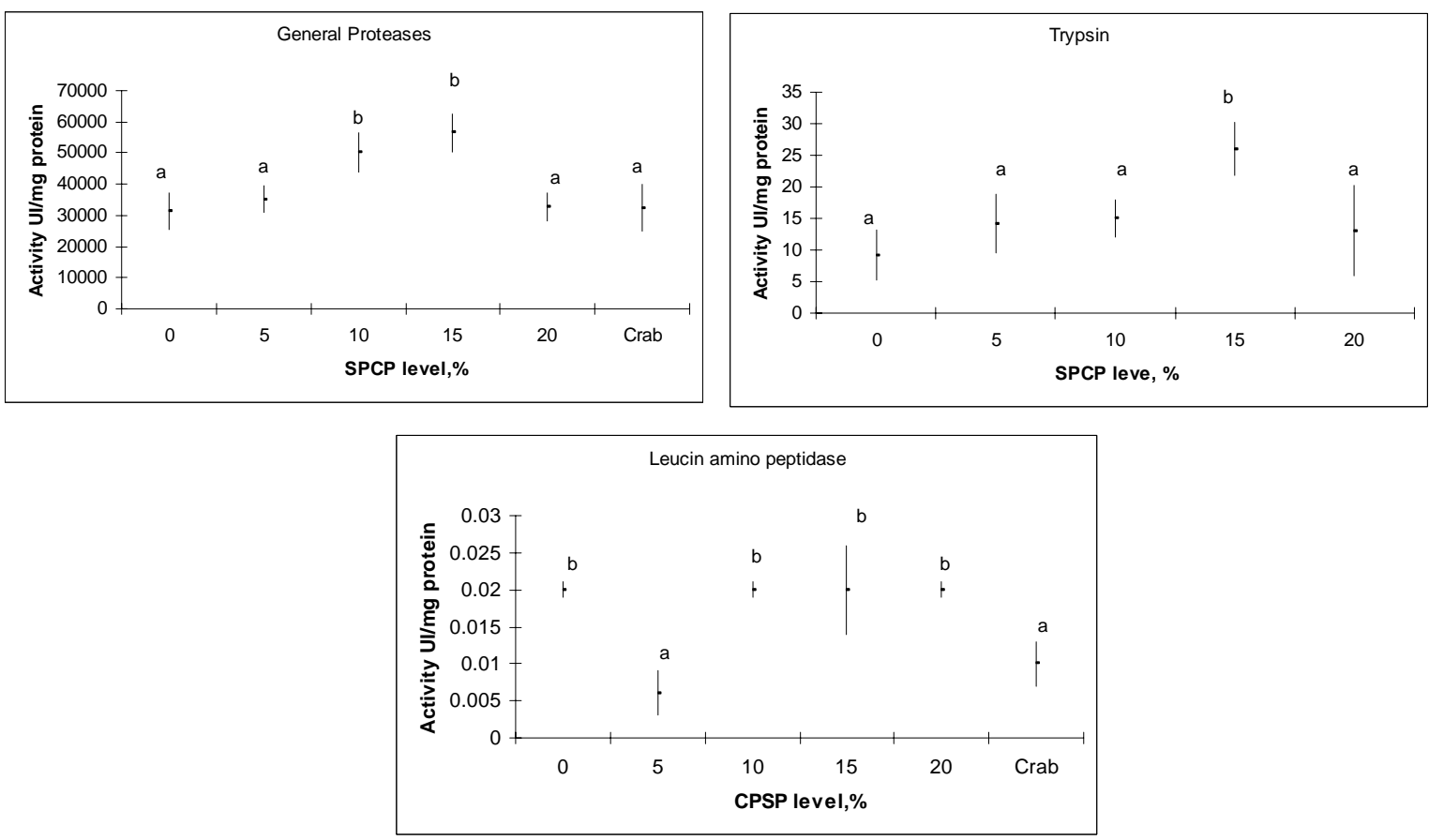

Fig. 7. General proteases, trypsin, and leucine amino peptidase of $O$. maya fed different CPSP levels or fresh crab. Mean \pm S.E. Different letters mean differences among treatments at a $p<0.05$ level. 

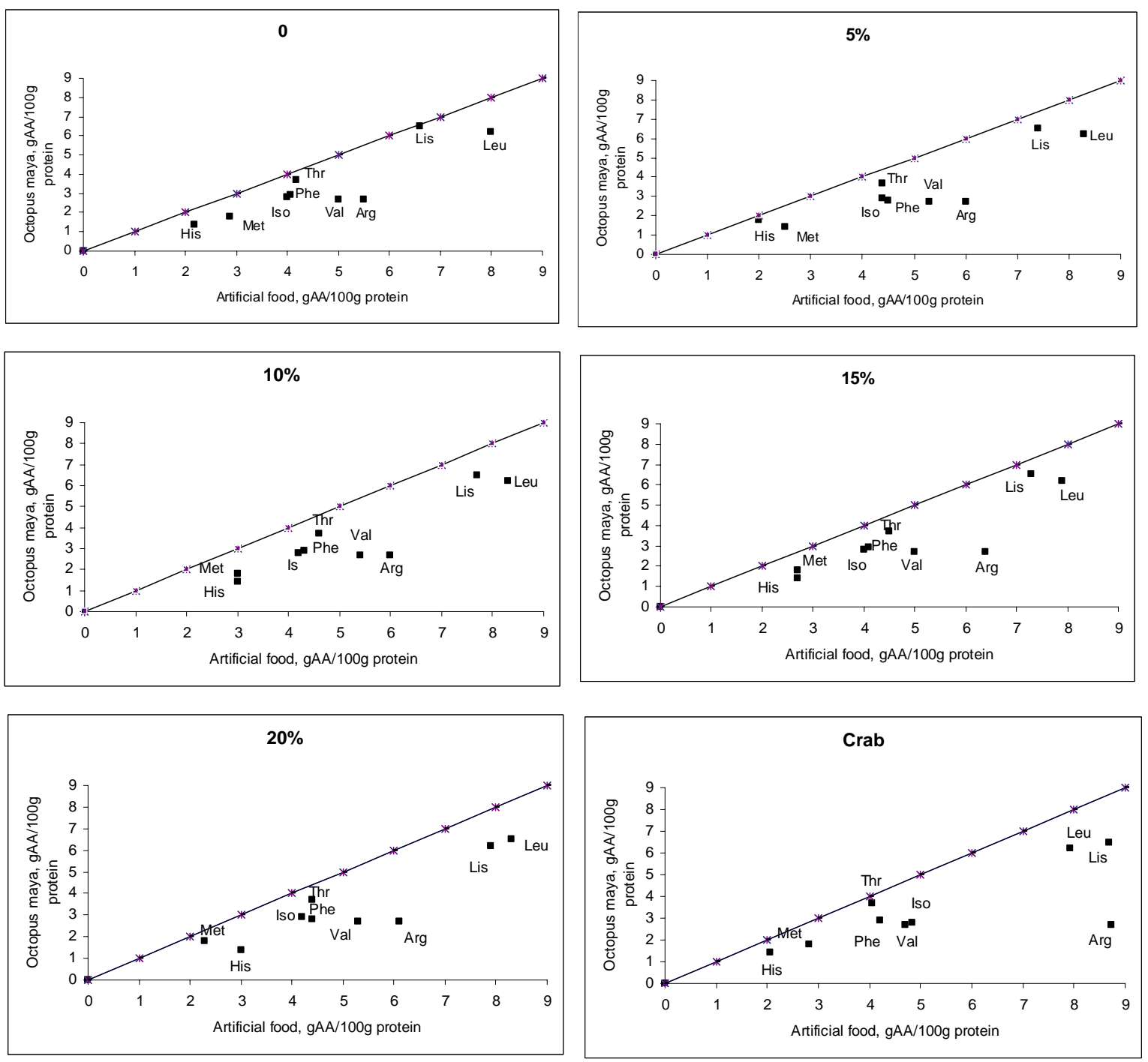

Fig. 8. Comparison of the total essential amino acid (EAA) profiles of $O$. maya and the total EAA profiles of different CPSP levels or fresh crab. Points above the line of slope 1 and intercept 0 suggest deficiencies for the amino acids in food. 

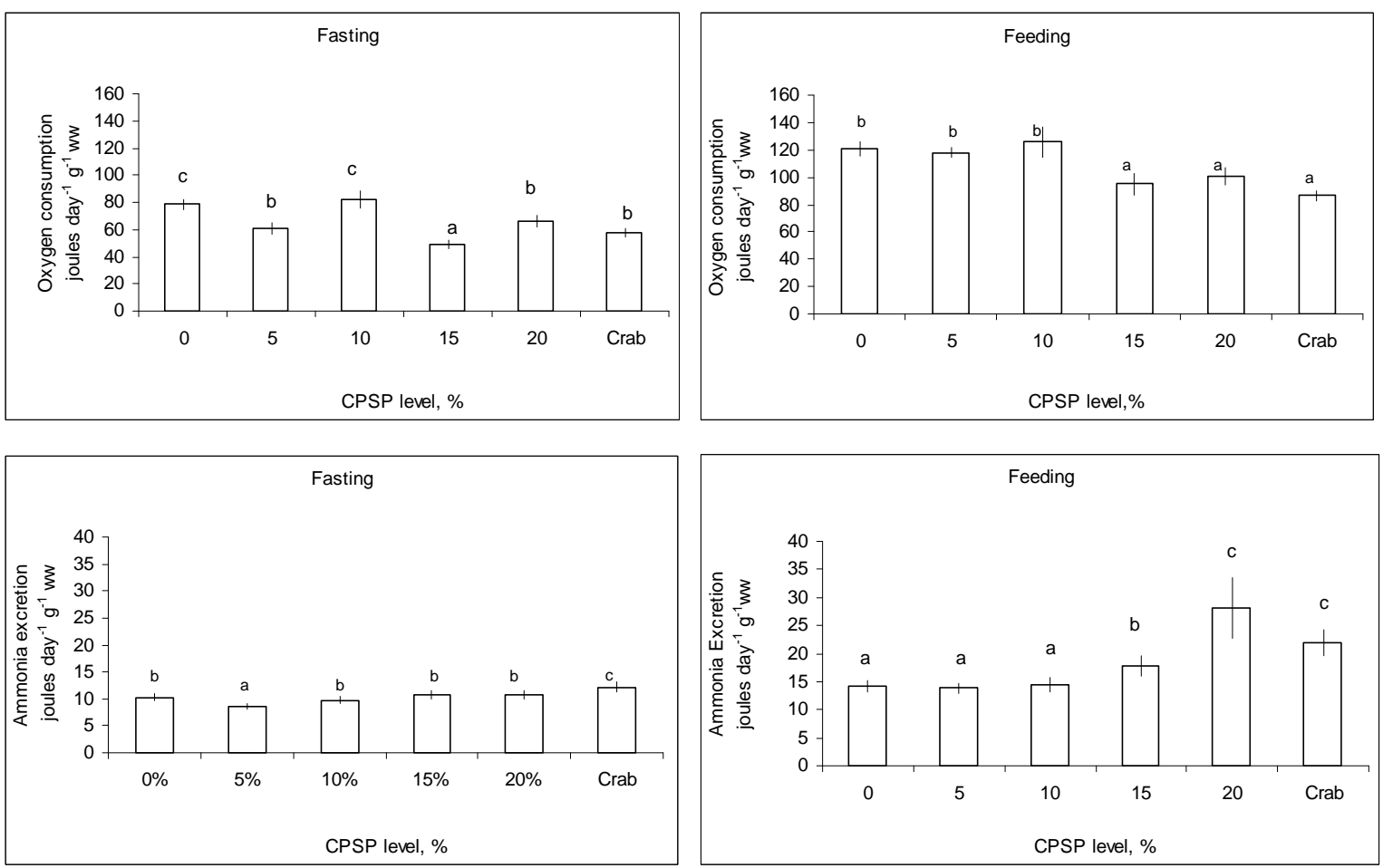

Fig. 9. Fasting and feeding oxygen consumption and ammonia excretion of $O$. maya fed different CPSP $^{80}$ levels and fresh crab. Mean \pm S.E. Different letters mean differences $(P<0.05)$ among treatments.
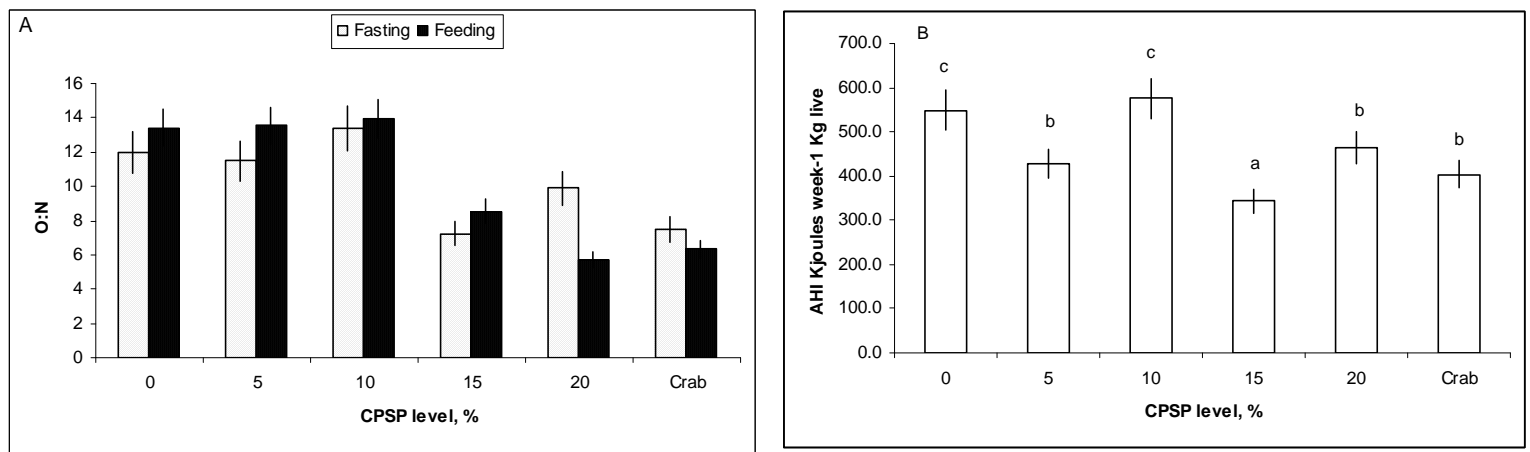

Fig. 10. Fasting and feeding O:N ratio $(A)$ and apparent heat increment $(\mathrm{AHI})(\mathrm{B})$ of $\mathrm{O}$. maya fed different CPSP levels or fresh crab. Mean \pm S.E. Different letters mean differences among treatments at a $p<0.05$ level. 
Table 1. Feeds composition for O. maya diets. g/100 g.

\begin{tabular}{lcccccc}
\hline & 0 & 5 & 10 & 15 & 20 & Crab \\
\hline Menhaden Fish meal & 41 & 41 & 41 & 41 & 41 & \\
CPSP $^{1}$ & 0 & 5 & 10 & 15 & 20 & \\
Profine $^{2}$ & 10 & 10 & 10 & 10 & 10 & \\
Squid meal $^{3}$ & 10 & 10 & 10 & 10 & 10 & \\
Milk serum $_{\text {Soybean lecithin }}$ & 25 & 20 & 15 & 10 & 5 & \\
Corn starch $^{\text {Vitamin mix }}$ & 1 & 1 & 1 & 1 & 1 & \\
Vitamin C & 4 & 4 & 4 & 4 & 4 & \\
Filler & 1 & 1 & 1 & 1 & 1 & \\
Alginate & 0.5 & 0.5 & 0.5 & 0.5 & 0.5 & \\
& 6.5 & 6.5 & 6.5 & 6.5 & 6.5 & \\
Chemical composition & 1 & 1 & 1 & 1 & 1 & \\
Dry Basis & & & & & & \\
Ash & & & & & & \\
Total lipids & 10.49 & 10.9 & 11.12 & 11.17 & 10.86 & 22 \\
Protein & 3.72 & 3.54 & 4.67 & 4.89 & 4.01 & 4.71 \\
Fiber & 33.87 & 38.09 & 35.3 & 37.67 & 39.33 & 56.3 \\
Carbohydrates & 1.54 & 1.45 & 0.73 & 1.32 & 1.48 & 2.47 \\
\hline
\end{tabular}

1. Fish protein concentrate, Sopropeche ${ }^{\Theta}$, France

2. Soybean protein concentrate

36.852

3. Loliguncula brevis

4. Vitamin mix provided by DSM ${ }^{@}$ nutritional products

5. Stay-C, 35\%, DSM ${ }^{@}$ nutritional products 
Table 2. Total amino acids content (mg/100 g protein) of sub adults of Octopus maya and experimental diets and crab (Callinectes sapidus ) used as food during the present study. Values as Mean \pm S.E.

\begin{tabular}{|c|c|c|c|c|c|c|c|c|c|c|c|c|c|c|}
\hline & \multirow{2}{*}{\multicolumn{2}{|c|}{ Octopus maya }} & \multicolumn{10}{|c|}{ CPSP level, \% } & \multirow{2}{*}{\multicolumn{2}{|c|}{ Crab }} \\
\hline & & & \multicolumn{2}{|l|}{0} & \multicolumn{2}{|l|}{5} & \multicolumn{2}{|c|}{10} & \multirow{2}{*}{\multicolumn{2}{|c|}{15}} & \multicolumn{2}{|l|}{20} & & \\
\hline \multicolumn{14}{|c|}{ Essential amino acids (EAA) } & \\
\hline His & $1.4 \pm 0.3$ & & $2.2 \pm$ & 0.2 & $2.5 \pm$ & 0.4 & $2.9 \pm$ & 0.2 & $2.7 \pm$ & -0.3 & $3.0 \pm$ & 0.5 & $2.0 \pm$ & 0.4 \\
\hline Met & $1.8 \pm 0.2$ & & $2.9 \pm$ & 0.1 & $2.0 \pm$ & 0.2 & $2.9 \pm$ & 0.7 & $2.7 \pm$ & 0.5 & $2.3 \pm$ & 0.3 & $2.8 \pm$ & 0.1 \\
\hline Ile & $2.8 \pm 0.7$ & & $4.0 \pm$ & 0.7 & $4.5 \pm$ & 0.4 & $4.2 \pm$ & 0.1 & $4.0 \pm$ & 0.8 & $4.4 \pm$ & 0.3 & $4.8 \pm$ & 0.4 \\
\hline Phe & $2.9 \pm 0.1$ & & $4.1 \pm$ & 0.3 & $4.4 \pm$ & 0.4 & $4.3 \pm$ & 0.2 & $4.1 \pm$ & 0.8 & $4.2 \pm$ & 0.1 & $4.2 \pm$ & 0.2 \\
\hline Thr & $3.7 \pm 0.3$ & & $4.2 \pm$ & 0.1 & $4.5 \pm$ & 0.4 & $4.6 \pm$ & 0.2 & $4.5 \pm$ & 0.6 & $4.4 \pm$ & 0.4 & $4.0 \pm$ & 0.4 \\
\hline Val & $3.0 \pm 0.2$ & & $5.0 \pm$ & 0.8 & $5.3 \pm$ & 0.2 & $5.4 \pm$ & 0.2 & $5.0 \pm$ & $=0.6$ & $5.3 \pm$ & 0.3 & $4.7 \pm$ & 0.5 \\
\hline Arg & $5.0 \pm 0.3$ & & $5.5 \pm$ & 0.3 & $6.0 \pm$ & 0.1 & $6.0 \pm$ & 0.9 & $6.4 \pm$ & 0.4 & $6.1 \pm$ & 0.1 & $8.7 \pm$ & 0.2 \\
\hline Lys & $6.5 \pm 0.3$ & & $6.6 \pm$ & 0.2 & $7.4 \pm$ & 0.3 & $7.7 \pm$ & 0.2 & $7.3 \pm$ & 0.2 & $9.3 \pm$ & 0.2 & $8.7 \pm$ & 0.2 \\
\hline Leu & $6.2 \pm 0.2$ & & $8.0 \pm$ & 0.3 & $8.3 \pm$ & 0.2 & $8.3 \pm$ & 0.2 & $7.9 \pm$ & -0.2 & $7.9 \pm$ & -0.4 & $7.9 \pm$ & 0.1 \\
\hline \multicolumn{15}{|c|}{ Non essential amino acids (NEAA) } \\
\hline Cys & $0.5 \pm 0.4$ & & $0.6 \pm$ & 0.4 & $0.5 \pm$ & 0.2 & $0.6 \pm$ & 0.8 & $0.6 \pm$ & 0.3 & $0.6 \pm$ & 0.3 & $1.1 \pm$ & 0.1 \\
\hline Trp & $0.6 \pm 0.2$ & & $1.0 \pm$ & 0.4 & $1.1 \pm$ & 0.3 & $1.3 \pm$ & 0.2 & $1.1 \pm$ & 0.1 & $1.1 \pm$ & 0.1 & $1.4 \pm$ & 0.3 \\
\hline Tyr & $1.1 \pm 0.1$ & & $2.6 \pm$ & 0.1 & $2.9 \pm$ & 0.6 & $2.9 \pm$ & 0.1 & $2.9 \pm$ & 0.6 & $2.9 \pm$ & 0.3 & $3.3 \pm$ & 0.2 \\
\hline Pro & $2.8 \pm 0.3$ & & $5.0 \pm$ & 0.2 & $5.1 \pm$ & 0.4 & $4.6 \pm$ & 0.6 & $4.4 \pm$ & 0.1 & $4.3 \pm$ & 0.1 & $3.3 \pm$ & 0.2 \\
\hline Ser & $3.7 \pm 0.6$ & & $4.6 \pm$ & 0.5 & $4.5 \pm$ & 0.4 & $4.6 \pm$ & 0.6 & $4.5 \pm$ & 0.2 & $4.3 \pm$ & 0.2 & $3.9 \pm$ & 0.3 \\
\hline Ala & $4.1 \pm 0.4$ & & $6.1 \pm$ & 0.5 & $6.4 \pm$ & 0.3 & $7.0 \pm$ & 0.4 & $6.9 \pm$ & -0.6 & $6.8 \pm$ & 0.3 & $5.7 \pm$ & 0.4 \\
\hline Gly & $4.7 \pm 0.4$ & & $5.3 \pm$ & 0.2 & $5.6 \pm$ & 0.1 & $5.7 \pm$ & 0.5 & $5.7 \pm$ & 0.6 & $5.7 \pm$ & 0.3 & $6.0 \pm$ & 0.2 \\
\hline Asp & $5.1 \pm 0.5$ & & $9.6 \pm$ & 0.5 & $9.9 \pm$ & 0.8 & $10.4 \pm$ & 0.3 & $10.0 \pm$ & $=0.4$ & $9.9 \pm$ & 0.6 & $10.3 \pm$ & 0.2 \\
\hline Glu & $8.9 \pm 0.4$ & & 15.6 & 0.3 & 15.4 & 0.3 & 14.8 & 0.7 & 14.2 & 0.1 & 13.8 & 0.2 & 17.1 & 0.4 \\
\hline \multicolumn{15}{|l|}{ Total } \\
\hline EAA & $33.4 \pm 0.3$ & $\mathrm{a}$ & $42.5 \pm$ & 0.3 & $44.8 \pm$ & 0.3 & $46.3 \pm$ & 0.3 & $44.5 \pm$ & $=0.5^{c}$ & $47.0 \pm$ & 0.3 & $48.0 \pm$ & $0.3^{d}$ \\
\hline NEAA & $31.4 \pm 0.4$ & a & $50.3 \pm$ & $0.3^{b}$ & $51.2 \pm$ & 0.4 & $51.9 \pm$ & 0.5 & $50.2 \pm$ & $0.3^{b}$ & $49.4 \pm$ & $0.3^{b}$ & $52.1 \pm$ & $0.3^{b}$ \\
\hline
\end{tabular}

Table 3. effect of CPSP level and fresh crab on energetic balance of $O$. may. Values as Kjoules week ${ }^{-1} \mathrm{Kg}^{-1} \mathrm{ww}$. Mean $\pm \mathrm{SE}$

\begin{tabular}{|c|c|c|c|c|c|c|c|c|c|c|c|c|c|c|c|c|c|}
\hline & \multicolumn{3}{|c|}{0} & \multicolumn{3}{|c|}{5} & \multicolumn{3}{|c|}{10} & \multicolumn{3}{|c|}{15} & \multicolumn{3}{|c|}{20} & \multicolumn{2}{|l|}{ Crab } \\
\hline$I$ & 4041 & +444.5 & $a$ & 3414 & +375.5 & $a$ & 3300 & +396.0 & $\mathrm{a}$ & 3368 & +404.2 & $a$ & 3488 & +383.7 & $\mathrm{a}$ & $4106+492.7$ & $\mathrm{a}$ \\
\hline Ab E, \% & 33.0 & \pm 8.8 & a & 47.0 & \pm 6.2 & $b$ & 36.0 & \pm 7.7 & a & 42.0 & \pm 4.9 & $b$ & 45.0 & \pm 3.9 & $b$ & $82 \pm 8.0$ & C \\
\hline$A b=A b E * I$ & 1333.5 & \pm 121.0 & a & 1604.6 & \pm 60.0 & c & 1188.0 & \pm 80.0 & a & 1414.6 & \pm 130.0 & b & 1569.6 & \pm 50.0 & c & $3366.9 \pm 40.0$ & d \\
\hline $\mathbf{U}$ & 172.1 & \pm 18.0 & a & 156.2 & \pm 15.0 & a & 169.5 & \pm 17.0 & a & 200.2 & \pm 18.0 & $a$ & 272.4 & \pm 18.0 & b & $238.8 \pm 18.0$ & $b$ \\
\hline$A s=R+P$ & & 56.1 & & & 34.8 & & & 78.1 & & & 40.3 & & & 7.9 & & 2016.2 & \\
\hline $\mathbf{R}_{\mathrm{AHI}}$ & 549.1 & \pm 35.3 & c & 428.1 & \pm 50.9 & a & 575.0 & \pm 50.1 & c & 344.1 & \pm 49.1 & C & 463.5 & \pm 31.2 & b & $404.1 \pm 32.1$ & b \\
\hline $\mathbf{R}_{\text {rout }}$ & 296.1 & \pm 30.0 & c & 396.9 & \pm 40.0 & $b$ & 305.9 & \pm 60.0 & c & 322.2 & \pm 40.0 & a & 241.0 & \pm 40.0 & b & $200.8 \pm 30.0$ & $b$ \\
\hline$R=R_{A H I}+R_{\text {rout }}$ & 845.2 & \pm 56.0 & C & 825.0 & \pm 38.0 & C & 880.9 & \pm 113.0 & c & 666.3 & \pm 81.0 & b & 704.5 & \pm 65.0 & b & $604.9 \pm 41.0$ & a \\
\hline $\mathbf{P}$ & -89.1 & \pm 46.4 & a & 59.8 & \pm 46.7 & $b$ & 97.2 & \pm 44.9 & $b$ & 174.0 & \pm 78.9 & d & 143.4 & \pm 34.9 & c & $1411.3 \pm 123.7$ & $\mathrm{e}$ \\
\hline $\mathrm{U} / \mathrm{I}, \%$ & 4.3 & & & 4.6 & & & 5.1 & & & 5.9 & & & 7.8 & & & 5.8 & \\
\hline $\mathrm{R} / \mathrm{I}, \%$ & 20.9 & & & 24.2 & & & 26.7 & & & 19.8 & & & 20.2 & & & 14.7 & \\
\hline $\mathrm{P} / \mathrm{I}, \%$ & -2.2 & & & 1.8 & & & 2.9 & & & 5.2 & & & 4.1 & & & 34.4 & \\
\hline U/Ab,\% & 12.9 & & & 9.7 & & & 14.3 & & & 14.2 & & & 17.4 & & & 7.1 & \\
\hline $\mathrm{R} / \mathrm{Ab}, \%$ & 22.2 & & & 24.7 & & & 25.7 & & & 22.8 & & & 15.4 & & & 6.0 & \\
\hline PIAb,\% & -6.7 & & & 3.7 & & & 8.2 & & & 12.3 & & & 9.1 & & & 41.9 & \\
\hline R/As, \% & 111.8 & & & 93.2 & & & 90.1 & & & 79.3 & & & 83.1 & & & 30.0 & \\
\hline PIAs,\% & -11.8 & & & 6.8 & & & 9.9 & & & 20.7 & & & 16.9 & & & 70.0 & \\
\hline
\end{tabular}

